\title{
Programmed Cell Death-1 Pathway Deficiency Enhances Autoimmunity Leading to Dacryoadenitis of Mice
}

\author{
Yutaka Sakurai, ${ }^{\dagger \dagger}$ Yoshihiko Usui, ${ }^{\ddagger}$ Takaaki Hattori, ${ }^{\ddagger}$ Masaru Takeuchi, ${ }^{*}$ Kei Takayama, ${ }^{*}$ Yoko Karasawa, ${ }^{*}$ Yoshiaki Nishio, ${ }^{*}$ \\ Naoyuki Yamakawa, ${ }^{\ddagger}$ Daizoh Saitoh, ${ }^{\dagger}$ Hiroshi Goto, ${ }^{\ddagger}$ and Masataka Ito ${ }^{\S}$
}

From the Department of Ophthalmology, ${ }^{*}$ the Division of Traumatology, ${ }^{\dagger}$ Research Institute, and the Department of Developmental Anatomy and Regenerative Biology, ${ }^{\S}$ National Defense Medical College, Saitama; and the Department of Ophthalmology, ${ }^{\ddagger}$ Tokyo Medical University, Tokyo, Japan

\author{
Accepted for publication \\ February 22, 2021. \\ Address correspondence to \\ Masataka Ito, M.D., Ph.D., \\ Department of Developmental \\ Anatomy and Regenerative \\ Biology, National Defense \\ Medical College, 3-2, Namiki, \\ Tokorozawa, Saitama 359- \\ 8513, Japan; or Yutaka Sakurai, \\ M.D., Department of Ophthal- \\ mology, National Defense \\ Medical College, 3-2, Namiki, \\ Tokorozawa, Saitama 359- \\ 8513, Japan. E-mail: ysaku@ \\ ndmc.ac.jp or masataka@ndmc. \\ ac.jp.
}

\begin{abstract}
Programmed cell death protein (PD)-1 is a coinhibitory molecule that suppresses immune response and maintains immune homeostasis. Moreover, the PD-1 pathway blocks cancers from being attacked by immune cells. Anti-PD-1 antibody therapy such as nivolumab improves survival in cancer patients. However, the occurrence of autoimmune inflammatory disorders in various organs has been increasingly reported as an adverse effect of nivolumab. Of the disorders associated with nivolumab, Sicca syndrome occurs in $3 \%$ to $11 \%$ of cases and has unknown pathologic mechanisms. Whether the absence of the PD-1 pathway causes functional and morphologic disorders in lacrimal glands was determined by analyzing PD-1 gene-knockout $\left(P d c d 1^{-/-}\right)$mice. Histopathologic analysis showed that $P d c d 1^{-/-}$mice developed dacryoadenitis beginning at 3 to 4 months of age, and deteriorated with age. Flow-cytometric analysis confirmed that cells infiltrating the affected lacrimal glands consisted mainly of $\mathrm{CD}^{+} \mathrm{T}$ cells and only a small proportion of $\mathrm{CD} 19^{+} \mathrm{B}$ cells. Among infiltrating T cells, the $\mathrm{CD}^{+}{ }^{+}$Th-cell subset consisted of Th1 cells producing interferon- $\gamma$ in an early stage of dacryoadenitis in $P d c d 1^{-/-}$mice. Experiments of lymphocyte transfer from $P d c d 1^{-/-}$into irradiated wild-type mice confirmed that $\mathrm{CD}^{+} \mathrm{T}$ cells from $P d c d 1^{-/-}$mice induced dacryoadenitis. These results indicate that PD-1 plays an important role in the prevention of autoimmune inflammatory disorders in lacrimal glands caused by activated CD4 ${ }^{+}$Th1 cells. (Am J Pathol 2021, 191: 1077-1093; https://doi.org/ 10.1016/j.ajpath.2021.02.014)
\end{abstract}

Coinhibitory molecules, such as cytotoxic $\mathrm{T}$ lymphocyte-associated antigen (CTLA)-4, B- and T-lymphocyte attenuator (BTLA), and programmed cell death (PD)-1 protein, negatively drive $\mathrm{T}$ cell-mediated immune response and maintain immune homeostasis. ${ }^{1,2}$ Ctla-4-deficient mice develop massive lymphoproliferative disease leading to the destruction of multiple organs, and die at 3 to 4 weeks of age. ${ }^{3}$ Btla-deficient mice with $129 \mathrm{SvE}$ background develop autoimmune inflammatory disease in the liver, salivary glands, lung, and pancreas. ${ }^{4}$

PD-1 is an inducible coinhibitory receptor and a member of the CD28/CTLA-4 receptor superfamily. ${ }^{1,5} \mathrm{PD}-1$ is expressed on activated T cells, B cells, natural killer T cells, and monocytes ${ }^{6}$ and delivers inhibitory signals. ${ }^{7}$ Ligands of PD-1 are PD-L1 and PD-L2. ${ }^{8}$ PD-L1 is expressed on various nonhematopoietic cells in organs such as the heart, lung, liver, kidney, pancreas, testis, and eye, and in stromal cells including tumor cells, as well as on T cells, B cells, DCs, and macrophages. ${ }^{9}$ In ocular tissue in mice, PD-L1 is expressed in cornea ${ }^{10}$ and retina. ${ }^{11}$ In contrast, PD-L2 is expressed preferentially on monocytes, macrophages, and DCs. ${ }^{12}$ PD-1 negatively regulates antigen receptor signaling on engagement with PD-L1 or PD-L2. The PD-1/PD-1 ligand pathway plays an important role in immune homeostasis, and protects tissues from autoimmune attack in physiologic conditions. ${ }^{13}$ Hence, PD-1 deficiency leads to various autoimmune diseases. Studies have demonstrated that PD-1 gene-knockout $\left(\mathrm{Pdcdl}^{-/-}\right)$mice develop

Supported by Japan Society for the Promotion of Science Grant-in-Aid 20K09840 for Scientific Research (M.T.).

Disclosures: None declared. 
lupus-like arthritis, glomerulonephritis, ${ }^{14}$ and autoimmune dilated cardiomyopathy. ${ }^{15}$ In humans, polymorphism of the gene encoding PD-1 protein is associated with a higher prevalence of rheumatoid arthritis and systemic lupus erythematosus, which suggests an inhibitory effect of PD-1 in the pathogenesis of these diseases. ${ }^{16,17}$

Moreover, in tumor immunity, the PD-1/PD-1 ligand pathway blocks cancers from being attacked by immune cells. This mechanism leads to tumor immune escape. Immune checkpoint inhibitors including anti-PD-1 antibodies such as nivolumab (Opdivo) and pembrolizumab, and anti-CTLA-4 antibodies such as ipilimumab could be an effective breakthrough in cancer immunotherapy. These immune checkpoint inhibitors drastically improve the survival rate in patients with advanced-cancer. ${ }^{18,19}$ Despite their efficacy, immune checkpoint inhibitors that may boost the immune system have been associated with unique complications. An increasing number of reports have shown that patients who are taking nivolumab for the treatment of cancers develop autoimmune inflammatory disorders in various organs, referred to as immune-related adverse events. ${ }^{20,21}$ Reported immune-related adverse events associated with nivolumab use include interstitial pneumonia, diarrhea, colitis, thyroid dysfunction, liver dysfunction, skin rash, vitiligo, type 1 diabetes, renal dysfunction, uveitis, arthritis, and sicca syndrome. ${ }^{18}$ Sicca syndrome constitutes $3 \%$ to $11 \%$ of the immune-related adverse events associated with nivolumab. ${ }^{19}$ Some patients with immune-related adverse events of sicca syndrome present with parotid gland swelling indicating salivary gland inflammation. However, an elevated level of serum anti-Ro (SSA) antibody has not been detected. ${ }^{19,22}$ The mechanism of sicca syndrome as a nivolumab-induced immune-related adverse event remains unclear.

Sjögren syndrome is one of the major autoimmune diseases that manifests sicca syndrome. In Sjögren syndrome, chronic inflammation in lacrimal glands (LGs) and salivary glands results in dysfunctional tear and saliva secretion. ${ }^{23}$ The diagnosis of Sjögren syndrome requires clinical examination, including an assessment of lacrimal and salivary gland functioning, a labial salivary gland biopsy, and testing for autoantibodies including anti-SSA and anti-lupus La protein (SSB) antibodies in the serum. The underlying immunologic mechanisms mediated by the infiltration of $\mathrm{CD}^{+}$and $\mathrm{CD} 8^{+} \mathrm{T}$ cells, $\mathrm{B}$ cells, natural killer $\mathrm{T}$ cells, macrophages, and DCs are involved in impaired secretory function. ${ }^{24-28}$

In the present study, $P d c d l^{-/-}$mice were used to investigate whether the absence of the PD-1 pathway affects immune homeostasis in LGs, and if so, whether the histopathologic and immunologic characteristics in this model resemble those of Sjögren syndrome.

\section{Materials and Methods}

\section{Mice}

Male and female C57BL/6 mice [referred to as wild type (WT)] and $P d c d 1^{-1-}$ mice were obtained from Riken BRC
(Tsukuba, Japan). All animal protocols were reviewed and approved by the Animal Ethics Committee of National Defense Medical College (Saitama, Japan), and the study conformed to the standards in the Association for Research in Vision and Ophthalmology Statement for Use of Animals in Ophthalmic and Vision Research.

\section{Measurements of Tears and Saliva}

Mouse tears and saliva were collected according to a protocol published previously, with some modifications. ${ }^{29}$ In brief, the mice were anesthetized with an i.p. injection of $60 \mathrm{mg} / \mathrm{kg}$ pentobarbital (Kyoritsu Seiyaku Co., Tokyo, Japan) and 16 $\mathrm{mg} / \mathrm{kg}$ xylazine (Bayer Healthcare, Leverkusen, Germany). Pilocarpine (Santen Pharmaceutical Co., Osaka, Japan) was injected i.p. ( $3 \mathrm{mg} / \mathrm{kg}$ body weight) to stimulate tear and saliva production under anesthesia. Tear fluid was collected from both eyes using $1 \mu \mathrm{L}$-sized capillaries (Drummond Scientific Company, Broomall, PA) at 10, 12, and 14 minutes after pilocarpine injection. Saliva was collected using a 1000$\mu \mathrm{L}$ micropipette immediately after pilocarpine injection for a duration of 10 minutes. The volumes of tear and saliva secreted were normalized by body weight for further analysis.

\section{Corneal Fluorescein Staining Score}

Corneal epithelial fluorescein staining was assessed in female WT and female $P d c d 1^{-1-}$ mice at 6 and 12 months old, as previously described. ${ }^{30}$ Briefly, $1 \mu \mathrm{L}$ of $1 \%$ sodium fluorescein was applied onto the ocular surface of the right eye under anesthesia. The ocular surface was washed with phosphate-buffered saline to remove excess fluorescein 3 minutes after fluorescein instillation, and corneal staining was evaluated using a slit-lamp biomicroscope (Haag-Streit, Köniz, Switzerland) under a cobalt blue light. Images were captured by digital camera. The severity of corneal epithelial fluorescein staining was scored using a standardized $\mathrm{Na}$ tional Eye Institute grading system of 0 to 3 for each of the five areas of the cornea. ${ }^{31}$

\section{Histologic Examination, IHC Analysis, and Transmission Electron Microscopy}

Both female WT and female $P d c d 1^{-/-}$mice at 3, 4, 6, and 12 months of age were studied. Under deep anesthesia induced using pentobarbital and xylazine, mice were perfused with $4 \%$ paraformaldehyde for fixation, and LGs and submandibular glands (SMGs) were excised and embedded in paraffin. Sections ( $4 \mu \mathrm{m}$ in thickness) were stained with hematoxylin and eosin. Similarly, histologic analyses of other organs including the lung, liver, kidney, pancreas, and stomach were performed in 4, 6, and 12-month-old female WT and $P d c d 1^{-1-}$ mice. Scoring of histopathologic grades of dacryoadenitis and sialadenitis was based on the method published previously, ${ }^{32}$ as follows: 0 indicates normal; 1 indicates one to five foci being 
composed of $>20$ mononuclear cells per focus; 2 indicates more than five such foci without significant parenchymal destruction; 3 indicates degeneration of parenchymal tissue; 4 indicates extensive lymphocytic infiltration of the glands and extensive parenchymal destruction; or 5 indicates severe destructive foci with focal fibrosis, ductal dilatation, and/or fatty infiltration in addition to the score 4 lesions. In each group, $>10$ glands were analyzed for histopathologic grading.

The severity of inflammatory lesions in the lung, liver, pancreas, stomach, and kidney was scored using the method published previously ${ }^{33}$ as follows: 0 indicates normal; 1 indicates mild/small foci of dense lymphocytic infiltration; 2 indicates moderate/multiple foci of dense/large activated lymphocytic infiltration with/without germinal center; or 3 indicates marked reactive/activated or atypical lymphocytic infiltration. Severity of kidney lesions was graded according to criteria published previously, ${ }^{14}$ as follows: 0 indicates normal; 1 indicates segmental mesangial proliferation and cell infiltration with $<50 \%$ of glomeruli affected; 2 indicates global mesangial proliferation and cell infiltration with $>50 \%$ of glomeruli affected; or 3 indicates crescent formation. In each group, more than eight organs were analyzed for histopathologic grading.

For immunohistochemistry analysis, paraffin sections were deparaffinized and rehydrated, and antigenic retrieval was performed by heating the sections in $10 \mathrm{mmol} / \mathrm{L}$ sodium citrate. The sections were blocked with peroxidase-blocking reagent (Dako Cytomation, Glostrup, Denmark) for $10 \mathrm{mi}-$ nutes and $2.5 \%$ horse serum for 30 minutes. The sections were incubated overnight at $4{ }^{\circ} \mathrm{C}$ with anti-Ki-67 antibody (Spring Bioscience, Pleasanton, CA; dilution 1:200). Ki-67 is a nuclear marker of proliferating cells. Subsequently, peroxidase-conjugated secondary antibody (ImmPress reagent; Vector Laboratories, Burlingame, CA) and 3,3'-diaminobenzidine-tetrachloride (Vector Laboratories) were used according to the manufacturer's instructions. Sections were counterstained with hematoxylin.

For goblet cell staining, eyeballs from 2, 6, and 12month-old female WT and $P d c d 1^{-1-}$ mice with upper and lower eyelids were fixed in $10 \%$ buffered formalin overnight and embedded in paraffin. Mid-sagittal sections of the specimens were made ( $5 \mu \mathrm{m}$ in thickness), and stained with Alcian Blue and periodic acid-Schiff for the identification of goblet cells. The density of goblet cells in the superior and inferior conjunctiva was calculated. The mean number of goblet cells from three nonconsecutive cross-section slides from each eye was calculated. ${ }^{34}$

For transmission electron microscopy, LGs dissected from 12-month-old $P d c d 1^{-1-}$ female mice were fixed in a solution of $2.5 \%$ glutaraldehyde and $2 \%$ paraformaldehyde in $0.1 \mathrm{~mol} / \mathrm{L}$ sodium cacodylate buffer ( $\mathrm{pH} 7.4)(1 / 2$ Karnovsky fixative) for 12 hours at $4^{\circ} \mathrm{C}$. Ultra-thin sections were then made as described previously, ${ }^{35}$ and were examined by transmission electron microscopy (JEM-1400Plus; Jeol, Tokyo, Japan).
Preparation of Single-Cell Suspension and Isolation of Lymphocytes from LGs

A single-cell suspension of LGs was prepared according to a protocol published previously with some modifications. ${ }^{36}$ In brief, small pieces of glands cut by micro scissors were digested in Dulbecco's modified Eagle's medium supplemented with $0.1 \%$ collagenase D (Sigma-Aldrich, St. Louis, MO) at $37^{\circ} \mathrm{C}$ for 60 minutes. Cell suspensions were filtered through a cell strainer (pore size, $40 \mu \mathrm{m}$; BD Biosciences, San Jose, CA).

For intracellular cytokine staining for flow cytometry, the lymphocytes in LGs of $P d c d 1^{-1-}$ mice were isolated using Ficoll-Paque Plus (GE Healthcare Life Sciences, Uppsala, Sweden).

\section{Flow Cytometry of Infiltrating Cells in LGs of Pdcd1 $1^{-/-}$ Mice}

The lymphocytes were preincubated with anti-CD16/32 antibody (clone 2.4G2; eBioscience, San Diego, CA) to avoid nonspecific binding of antibodies to $\mathrm{Fc} \gamma$ receptors. The cells were then stained with anti-mouse CD45 (fluorescein isothiocyanate; clone 30-F11), anti-mouse CD3 (Pacific Blue; clone 17A2), anti-mouse CD4 (APC; clone GK1.5), anti-mouse CD8 (PE; clone 53-6.7), and antimouse CD19 (APC; clone 6D5) at $4^{\circ} \mathrm{C}$ for 30 minutes (all, BioLegend, San Diego, CA). Negative controls were stained with isotype control IgG.

For intracellular cytokine staining of infiltrating $\mathrm{CD}^{+}$ $\mathrm{T}$ cells in LGs of 4-month-old $P d c d 1^{-1-}$ mice, lymphocytes were isolated from LGs of 4-month-old female $P d c d 1^{-1-}$ mice. The cells from 20 LGs of 10 female $P d c d 1^{-1-}$ mice aged 4 months were analyzed in each experiment. Isolated lymphocytes were suspended in RPMI 1640 medium containing 10\% fetal bovine serum and $100 \mu \mathrm{g} / \mathrm{mL}$ penicillin/streptomycin, and stimulated with phorbol 12-myristate 13-acetate $(50 \mathrm{ng} / \mathrm{mL})$ and ionomycin $(500 \mathrm{ng} / \mathrm{mL})$ for 4 hours at $37^{\circ} \mathrm{C}$ in $5 \% \mathrm{CO}_{2}$. Brefeldin A $(10 \mu \mathrm{g} / \mathrm{mL})$ was added for the last 2 hours (all, Sigma-Aldrich). The Cytofix/Cytoperm fixation/permeabilization solution kit (BD Biosciences) was used for the fixation and permeabilization of lymphocytes, which were stained with anti-mouse CD4 (fluorescein isothiocyanate; clone GK1.5; BioLegend), anti-mouse interferon (IFN)- $\gamma$ (APC; clone XMG1.2; BioLegend), anti-mouse Il-4 (Brilliant Violet 421; clone 11B11; BioLegend), anti-mouse Il-17A (Brilliant Violet 421; clone TC1118H10.1; BioLegend), and Il-21 (APC; clone FFA21; eBioscience). The stained cells were analyzed using a flow cytometer (FACSCanto II; BD Biosciences). Data were processed using the BD FACSDiva software (BD Biosciences). Fluorescence Minus One controls were used to determine the cutoff points between background fluorescence and positive populations. For flow-cytometric analyses of infiltrating cells in LGs, two independent experiments were performed. 


\section{Adoptive Cell Transfer}

Adoptive transfer of $\mathrm{CD} 4^{+} \mathrm{T}$ cells or $\mathrm{B}$ cells was performed by i.v. injection into tail veins of irradiated sex-matched 2-month-old C57BL/6 mice. In this experiment, both male and female mice were used as donors. Single cell suspensions were collected from spleen and cervical lymph nodes of 4-month-old $P d c d 1^{-1-}$ mice or WT mice. $\mathrm{CD} 4^{+} \mathrm{T}$ cells or $\mathrm{CD} 19^{+} \mathrm{B}$ cells were purified by positive selection with $\mathrm{CD} 4^{+}$or $\mathrm{CD} 19^{+}$microbeads (Miltenyi Biotec, Bergisch Gladbach, Germany). Then, $1 \times 10^{7} \mathrm{CD}^{+} \mathrm{T}$ cells or $\mathrm{CD} 19^{+} \mathrm{B}$ cells were transferred i.v. into recipient mice 6 to 8 hours after they were given $300 \mathrm{rad}$ of $\gamma$ irradiation. The number of cells of i.v. adoptive transfer conformed to a protocol published previously. ${ }^{37}$ The measurement of tear volume and histopathologic analysis in recipient mice were performed at 7 weeks after adoptive transfer. Tissue sections from organs of recipient mice were stained with hematoxylin and eosin and graded histopathologically according to the method described in the previous paragraph.

\section{RNA Isolation and Quantitative Real-Time PCR}

To characterize helper T-cell phenotype associated with dacryoadenitis in $P d c d I^{-1-}$ mice, mRNA levels of IFN- $\gamma$, Il-4, Il-17A, Il-21, Il-1 $\beta$, tumor necrosis factor (TNF)- $\alpha$, Il-6, C-C motif chemokine ligand (Ccl)-3, Ccl-5, Cxcl-9, Cxcl-10, Ccl-20, Ccl-22, and 18S ribosomal RNA as an endogenous control were evaluated. Total RNA was extracted from LGs of female WT and female $P d c d 1^{-1-}$ mice using an RNA isolation kit (RNeasy Plus Mini kit; Qiagen, Oosterhout, the Netherlands) according to the manufacturer's protocol. RNA was reverse-transcribed to cDNA by using the PrimeScript RT master mix kit (Takara Bio, Shiga, Japan) according to the manufacturer's protocol. Quantitative real-time PCR was performed using specific minor groove binder probes (TaqMan; Applied Biosystems, Foster City, CA) and PCR master mix (TaqMan Gene Expression Master Mix; Applied Biosystems), by a commercial thermocycling real-time PCR system (Fast 7900HT; Applied Biosystems). The primers are described in Table 1. RNA levels were normalized to the level of $18 \mathrm{~S}$ ribosomal RNA and calculated as $\Delta \Delta C_{\tau}{ }^{38}$ The mean $\Delta C_{\tau}$ value of 4month-old WT mice group was used as the calibrator.

\section{Measurement of Anti-SSA and Anti-SSB Antibodies in} Serum and Il-21 Protein in LGs by ELISA

The concentrations of anti-SSA and anti-SSB autoantibodies in the serum of WT and $P d c d I^{-/-}$mice at 6 months and 13 to 14 months of age were measured using an enzyme-linked immunosorbent assay (ELISA) kit (Alpha Diagnostic International Inc., San Antonio, TX) according to the manufacturer's protocols. Serum from WT and $P d c d I^{-1-}$ mice were used at 1:100 dilution. The protein concentration of Il21 in LGs of WT and $P d c d 1^{-1-}$ mice were measured using
Table 1 Target Genes and Assay Identification of Quantitative Real-Time PCR

\begin{tabular}{ll}
\hline Target gene & Assay ID \\
\hline Endogenous control & \\
18S rRNA & Mm03928990 \\
Cytokine & \\
Ifng & Mm00801778 \\
Il1b & Mm00434228 \\
Il4 & Mm00445259 \\
Il6 & Mm00446190 \\
Il17a & Mm00439619 \\
Il21 & Mm00517640 \\
Tnfa & Mm00443260 \\
Th1-related chemokine & \\
Ccl3 & Mm00441259 \\
Ccl5 & Mm01302428 \\
Cxcl9 & Mm00445235 \\
Th17-related chemokine & \\
Ccl20 & Mm01268754 \\
Th2-related chemokine & \\
Ccl22 & Mm00436439 \\
\hline
\end{tabular}

an ELISA kit (R\&D Systems Inc., Minneapolis, MN) according to the manufacturer's protocols. For the measurement of Il-21 by ELISA, the LGs of 6-month-old female WT and $P d c d l^{-1-}$ mice were homogenized in radioimmunoprecipitation assay buffer using a homogenizer.

\section{Statistical Analysis}

For statistical comparisons between two groups, parametric data (histologic grading scores of LGs and SMGs after transfer experiments) that had the different variances were tested by the Welch $t$-test, and nonparametric data (tear and saliva volumes, and gene expression levels) were analyzed by the $U$-test. For multiple comparisons of histopathologic scores in LGs and SMGs, two-way analysis of variance with the Tukey post hoc test was used. $P<0.05$ was considered to be statistically significant.

\section{Results}

Measurements of Tear and Saliva Secretion in $\mathrm{Pdcd}^{-/-}$Mice

The volumes of tear and saliva secretion in WT and $P d c d 1^{-1-}$ mice at 6 and 12 months are shown in Figure 1. The volumes of tear were significantly less in both male and female $P d c d 1^{-1-}$ mice compared to WT mice at 6 and 12 months (Figure 1A). While there were no significant differences in the volumes of secreted saliva in both male and female $P d c d 1^{-1-}$ mice compared to WT mice at 6 months, the volumes were much less in male and female $P d c d 1^{-1-}$ mice at 12 months, as compared to WT mice (Figure 1B). A sex difference in tear secretion was found in $P d c d l^{-l-}$ mice at 12 months, with the volume of tear being significantly less in female than in male 
A

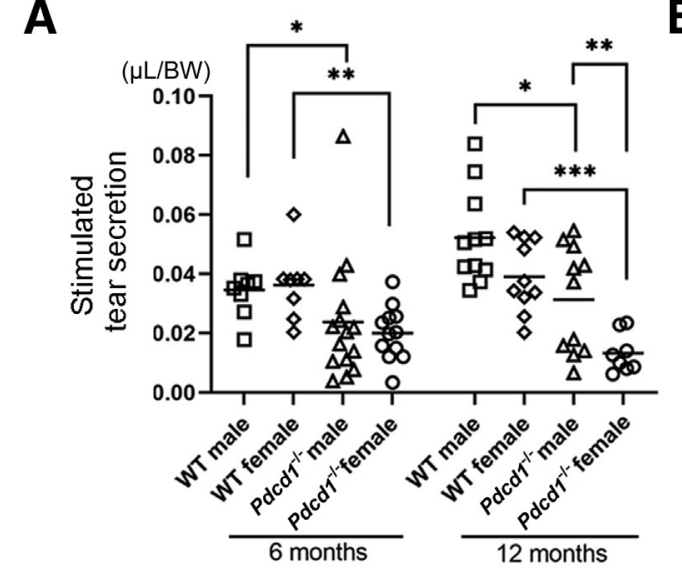

C

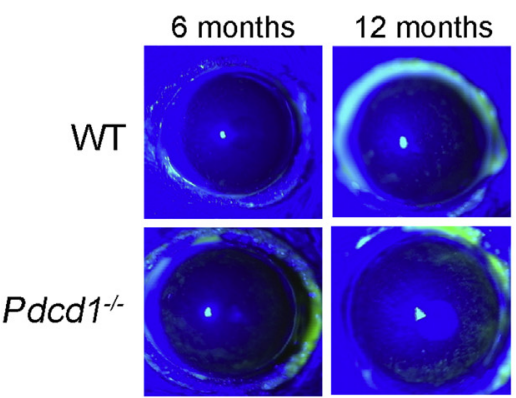

$\mathbf{E}$

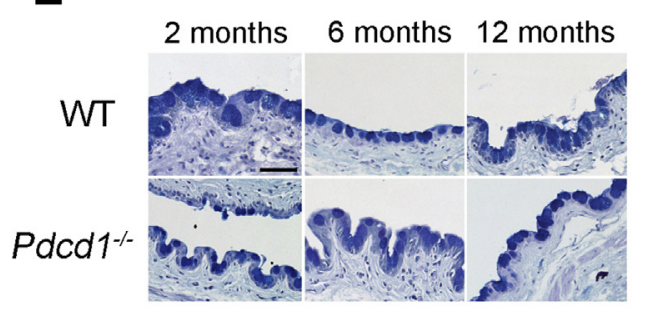

B

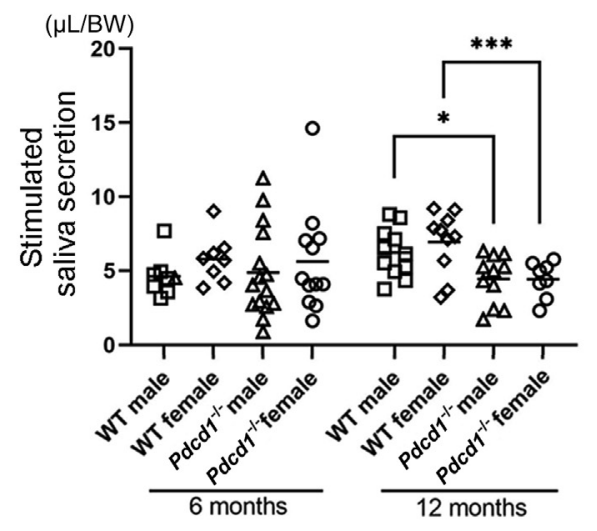

D

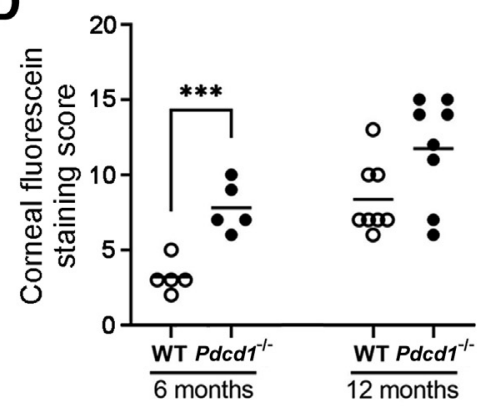

$\mathbf{F}$

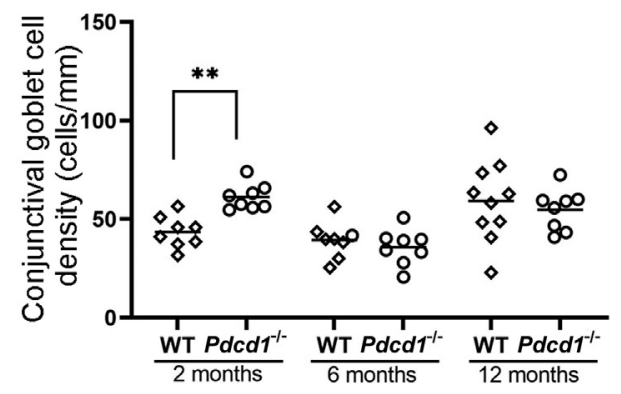

Figure 1 Exocrine function of lacrimal and submandibular glands and assessment of ocular surface in wild-type (WT) and Pdcd1 $1^{-/-}$mice. A and B: The volumes of tear (A) and saliva (B) secretion in male WT, female WT, male $P d c d 1^{-/-}$mice and female $P d c d 1^{-/-}$mice aged 6 and 12 months are shown. C and D: The corneal fluorescein staining (C) and scoring (D) in female WT and female $P d c d 1^{-/-}$mice aged 6 and 12 months. E and F: representative images of conjunctival goblet cells stained with Alcian Blue and periodic acid-Schiff (E) and their density (F) in female WT mice and female $P d c d 1^{-1-}$ mice aged 2,6 , and 12 months. Data are expressed as means (horizontal bars). $n=8$ mice per group ( $\mathbf{D}$ and $\mathbf{F}$ ); $n=10$ to 15 mice per group $(\mathbf{A}$ and $\mathbf{B}) ; n=8$ mice per group (D and $\mathbf{F}) .{ }^{*} P<0.05,{ }^{* *} P<0.01$, and ${ }^{* *} P<0.001$ (U-test). Scale bar $=50 \mu \mathrm{m}$.

mice; this difference was not significant in WT mice (Figure 1A). There were no sex differences in saliva secretion in $P d c d 1^{-l-}$ or WT mice (Figure 1B).

\section{Assessment of Ocular Surface}

Corneal fluorescein staining score and conjunctival goblet cell density were assessed in the evaluation of ocular surface conditions in WT and $P d c d l^{-1-}$ mice. The corneal fluorescein staining scores in $P d c d I^{-1-}$ mice were significantly higher than those in WT mice at 6 months of age (Figure 1C and D). Corneal fluorescein staining scores tended to increase with age in both WT and $P d c d 1^{-1-}$ mice, but the differences were not significant. Conjunctival goblet cell densities in $P d c d I^{-1-}$ mice were significantly higher than those in WT mice at 2 months of age, but there were no significant differences between WT and $P d c d 1^{-1-}$ mice at 6 and 12 months of age (Figure 1E and F).

\section{Histopathologic Findings in LGs and SMGs}

Representative histologic sections of LGs and SMGs in WT and $P d c d 1^{-1-}$ female mice at different ages are shown in Figure 2. In LGs, lymphocytic infiltrates were not observed in WT mice at 4 and 6 months, although mild lymphocytic infiltrates without remarkable acinar atrophy were found at 12 months (Figure 2, A, E, and I). In $P d c d 1^{-1-}$ mice, perivascular lymphocytic infiltration foci 


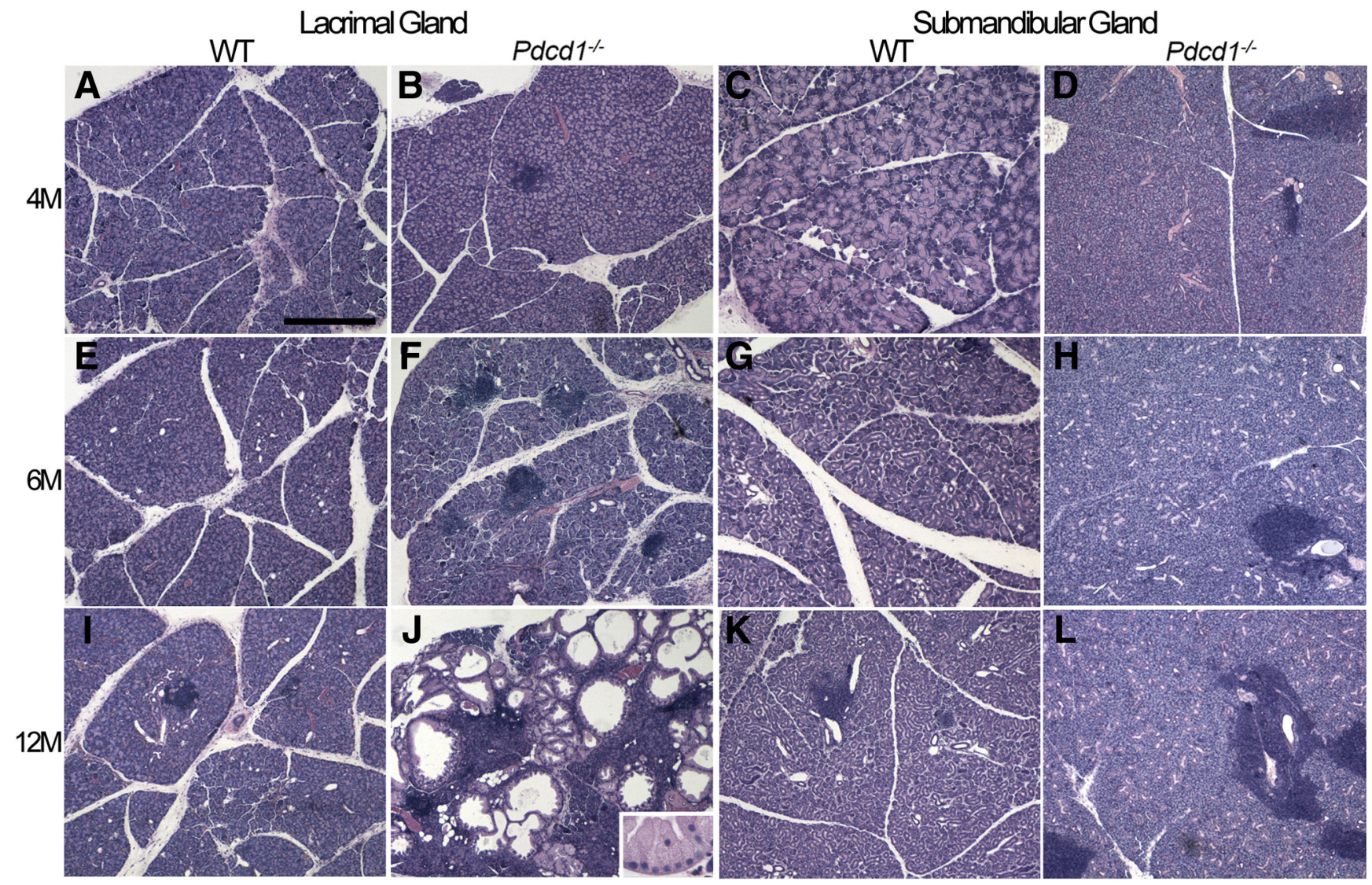

Figure 2 Histologic features of lacrimal glands (LGs) and submandibular glands (SMGs) in Pdcd1 ${ }^{-/-}$mice. A-L: Representative micrographs of hematoxylin and eosin-stained extraorbital LGs (A, B, E, F, I, and J) and SMGs (C, D, G, H, K, and L) from female wild-type (WT) mice (A, C, E, G, I, and K) and female $P d c d 1^{-/-}$mice (B, D, F, H, J, and $\left.\mathbf{L}\right)$ aged 4 months (4M) (A-D), 6 months (6M) (E-H), and 12 months (12M) (I-L). Inflammatory cell infiltration into LGs and SMGs is observed at the age of 4 months, and deterioration of histologic findings with age is evident in $P d c d 1^{-/-}$mice. The inset in $\mathbf{J}$ shows higher magnification of the dilatated acinus. Scale bar $=250 \mu \mathrm{m}$.

were observed from 4 months, which continued to increase in number and size with age (Figure 2, B and F). In these mice, foci of infiltrating lymphocytes coalesced and expanded to the whole gland, and collapse and dilatation of terminal acini were observed at 12 months (Figure 2J).

Plenty of clear secretion vesicles were seen in the dilatated acinus (Figure 2J). In SMGs, although there was no or mild lymphocytic infiltration in WT mice (Figure 2, C, G, and $\mathrm{K}$ ), lymphocytic infiltrates in $P d c d 1^{-1-}$ mice were observed from 4 months of age (Figure 2D), and the foci increased with age (Figure 2, $\mathrm{H}$ and L). Lymphocytic infiltrates were apparently milder in SMGs than in LGs in $P d c d 1^{-1-}$ mice at all ages. Similar histopathologic findings were observed in male WT and $P d c d 1^{-1-}$ mice (data not shown).

Histopathologic grading scores of dacryoadenitis and sialadenitis in both male and female mice were assessed. All LGs in $P d c d 1^{-1-}$ mice showed elevated scores at 4 months, and thereafter the scores in $P d c d l^{-1-}$ mice were significantly higher than those in age-matched WT mice (Figure $3 \mathrm{~A}$ and $\mathrm{B}$ ). Furthermore, sex differences were observed in $P d c d 1^{-l-}$ mice. Histopathologic scores in both LGs and SMGs were significantly higher in female mice than in male mice at 6 and 12 months of age (Figure 3, C and D).

To investigate the inflammatory changes in other organs of $P d c d I^{-1-}$ mice, histopathologic examinations of the stomach, lung, liver, pancreas, and kidney were performed in female WT and $P d c d I^{-1-}$ mice at ages 4,6 , and 12 months. Inflammatory cell infiltration was observed in all of those organs in $P d c d l^{-1-}$ mice (Supplemental Figure S1). At 4 months of age, $50 \%$ of $P d c d 1^{-1-}$ mice had inflammatory lesions in the liver, while there were no inflammatory lesions in the other organs (Table 2).

Cell proliferation in LGs in female $P d c d 1^{-1-}$ mice was evaluated using the expression of Ki-67 (Figure 4, A-F). Immunoreactivity of Ki-67 was observed mainly in infiltrating cells. The percentage of Ki-67-positive cells among infiltrating cells looked the highest at 4 months compared to those at 6 or 12 months.

Transmission electron microscopy of LGs from a 12 month-old female $P d c d I^{-1-}$ mouse showed that in the unaffected area, structures of terminal acini looked normal, with epithelial cells filled by secretion vesicles (Figure 4G). However, in the area with inflammatory cell infiltration, many migrating cells, mostly lymphocytes, were observed 

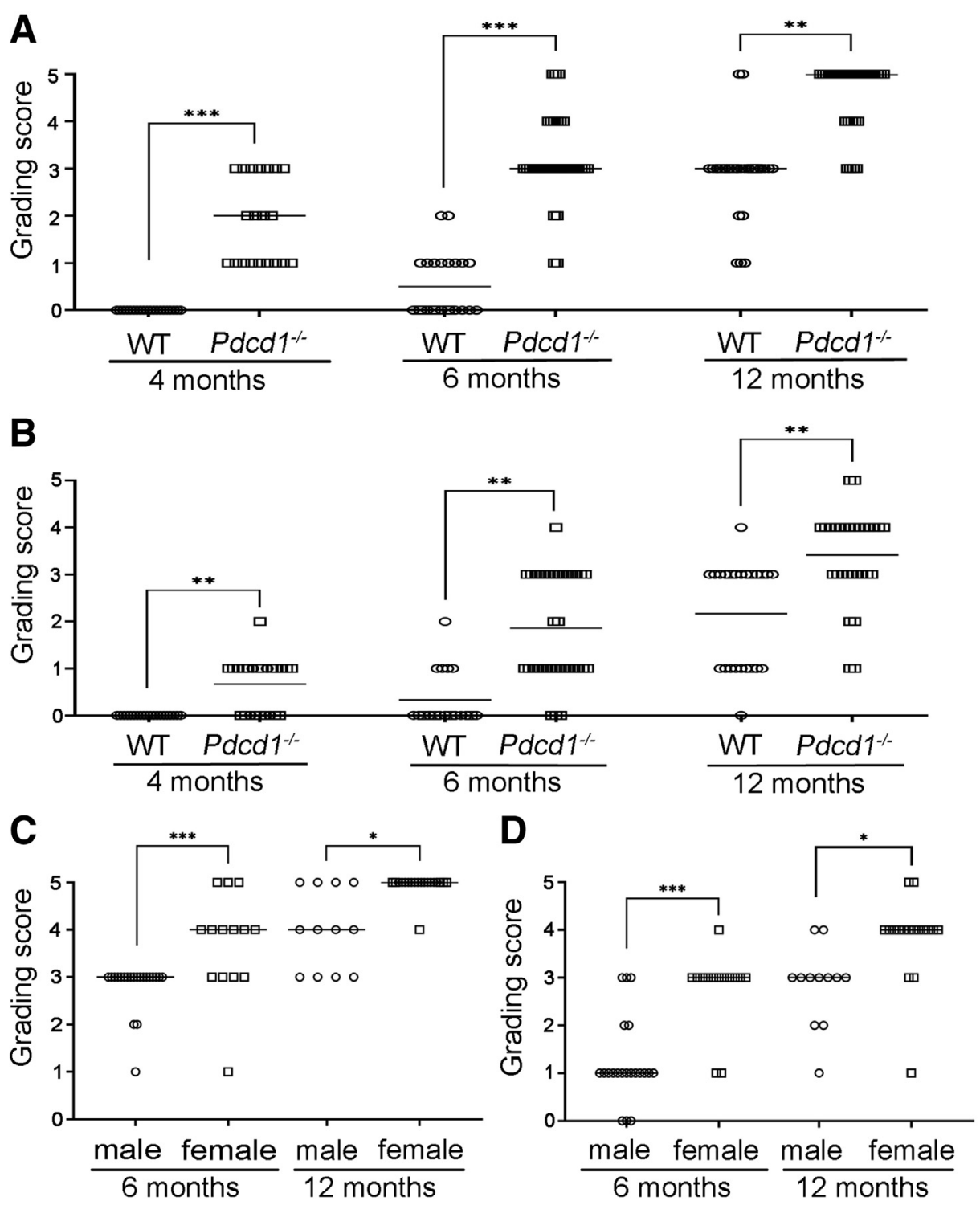

Figure 3 Histopathologic grading scores of lacrimal glands (LGs) and submandibular glands (SMGs) of wild-type (WT) and Pdcd $1^{-/-}$mice. A and B: Histopathologic scores of LGs (A) and SMGs (B) from both male and female WT and both male and female Pdcd1 ${ }^{-1-}$ mice aged 4, 6, and 12 months. The histopathologic scores in Pdcd1 ${ }^{-/-}$mice are significantly higher than those in WT mice at all ages in both LGs and SMGs. C and D: Histopathologic scores of LGs (C) and SMGs (D) from male and female $P d c d 1^{-1-}$ mice aged 6 and 12 months. The histopathologic scores of both LGs and SMGs are significantly higher in female than in male $P d c d 1^{-1-}$ mice at 6 and 12 months. ${ }^{*} P<0.05$, ${ }^{* *} P<0.01$, and ${ }^{* * *} P<0.001$ (two-way analysis of variance with Tukey post hoc testing).

(Figure 4, H and I), and some of which were invading into acinar and ductal epithelium (Figure 4I). Some apoptotic cells with condensed and/or cleaved nuclei were also observed (Figure 4, H and I).

\section{Flow Cytometric Analyses of Infiltrating Inflammatory Cells in LGs}

Figure 5 shows flow-cytometric analyses of the proportions of $\mathrm{CD}^{+}, \mathrm{CD}^{+}, \mathrm{CD} 8^{+}$, and $\mathrm{CD} 19^{+}$cells in the infiltrating cell population in LGs in female $P d c d 1^{-1-}$ mice at 3.5 and 4.5 months of age. At 3.5 months, $\mathrm{CD}^{+} \mathrm{T}$ cells were dominating, with the percentage being markedly higher than that of $\mathrm{CD} 19^{+} \mathrm{B}$ cells among infiltrating cells in LGs (Figure 5, A and C), while, at 4.5 months, the percentage of $\mathrm{CD} 19^{+} \mathrm{B}$ cells increased and became dominating among infiltrating cells (Figure 5, B and C). At 3.5 months, both $\mathrm{CD}^{+}{ }^{+} \mathrm{T}$ cells and $\mathrm{CD} 8^{+} \mathrm{T}$ cells were detected among $\mathrm{CD} 3^{+}$ $\mathrm{T}$ cells infiltrating in LGs; however, the CD4/CD8 T-cell ratios were varied among individual $P d c d 1^{-1-}$ mice (Figure 5, D and E).

\section{Serum Levels of Anti-SSA and Anti-SSB Antibodies}

Levels of anti-SSA and anti-SSB antibodies were measured by ELISA in 13- to 14-month-old WT and $P d c d 1^{-1-}$ mice. Levels of both anti-SSA and anti-SSB antibodies were not 
Table 2 Histologic Grading Scores of Various Organs from WT and $P d c d 1^{-/-}$Mice

\begin{tabular}{|c|c|c|c|c|c|c|}
\hline \multirow[b]{2}{*}{ Organ/grade } & \multicolumn{2}{|c|}{4 months } & \multicolumn{2}{|c|}{6 months } & \multicolumn{2}{|c|}{12 months } \\
\hline & $\overline{\text { WT }}$ & $P d c d 1^{-/-}$ & $\overline{W T}$ & $P d c d 1^{-/-}$ & $\overline{W T}$ & $P d c d 1^{-/-}$ \\
\hline \multicolumn{7}{|l|}{ Stomach } \\
\hline Grade 0 & 8 & 8 & 8 & 7 & 5 & 2 \\
\hline Grade 1 & 0 & 0 & 0 & 1 & 3 & 5 \\
\hline Grade 2 & 0 & 0 & 0 & 0 & 0 & 3 \\
\hline Grade 3 & 0 & 0 & 0 & 0 & 0 & 0 \\
\hline \multicolumn{7}{|l|}{ Lung } \\
\hline Grade 0 & 8 & 8 & 8 & 7 & 7 & 2 \\
\hline Grade 1 & 0 & 0 & 0 & 1 & 0 & 2 \\
\hline Grade 2 & 0 & 0 & 0 & 0 & 1 & 5 \\
\hline Grade 3 & 0 & 0 & 0 & 0 & 0 & 1 \\
\hline \multicolumn{7}{|l|}{ Liver } \\
\hline Grade 0 & 8 & 4 & 7 & 3 & 0 & 6 \\
\hline Grade 1 & 0 & 3 & 1 & 4 & 8 & 2 \\
\hline Grade 2 & 0 & 1 & 0 & 1 & 0 & 2 \\
\hline Grade 3 & 0 & 0 & 0 & 0 & 0 & 0 \\
\hline \multicolumn{7}{|l|}{ Pancreas } \\
\hline Grade 0 & 8 & 8 & 8 & 8 & 5 & 6 \\
\hline Grade 1 & 0 & 0 & 0 & 0 & 2 & 2 \\
\hline Grade 2 & 0 & 0 & 0 & 0 & 1 & 2 \\
\hline Grade 3 & 0 & 0 & 0 & 0 & 0 & 0 \\
\hline \multicolumn{7}{|l|}{ Kidney } \\
\hline Grade 0 & 8 & 8 & 8 & 5 & 0 & 0 \\
\hline Grade 1 & 0 & 0 & 0 & 3 & 8 & 3 \\
\hline Grade 2 & 0 & 0 & 0 & 0 & 0 & 7 \\
\hline Grade 3 & 0 & 0 & 0 & 0 & 0 & 0 \\
\hline
\end{tabular}

significantly different between WT and $P d c d I^{-1-}$ mice at 6 and 13 to 14 months (Figure 6, A and B).

\section{Expression of PD-1 Ligands on LGs with Dacryoadenitis}

To investigate the protein expression of PD-1 ligands (PD-L1 and PD-L2) in LGs, flow-cytometric analyses were performed using collagenase-digested LG cells. Neither PD-L1 nor PD-L2 was detected on $\mathrm{CD}^{-} 5^{-}$nonhematopoietic cells in LGs in $P d c d 1^{-1-}$ mice at 4 months (Figure 6, C and E), while strong expression of PD-L1 and mild expression of PD-L2 were detected on CD45 ${ }^{+}$infiltrating lymphocytes in LGs (Figure 6, D and F).

\section{Cytokine Production by $\mathrm{CD}^{+} \mathrm{T}$ Cells in LGs of}

\section{Pdcd1 ${ }^{-/}$Mice with Dacryoadenitis}

To characterize the $\mathrm{CD} 4^{+}$T-cell subsets involved in the development of dacryoadenitis in $P d c d 1^{-/-}$mice, cytokine production in $\mathrm{CD}^{+} \mathrm{T}$ cells isolated from LGs in female $P d c d 1^{-1-}$ mice aged 4 months was analyzed after in vitro stimulation with phorbol 12-myristate 13-acetate and ionomycin. $\mathrm{CD}^{+} \mathrm{T}$ cells infiltrating the LGs produced IFN- $\gamma$ but not Il-4, Il-17, or Il-21 (Figure 7, A and B). The percentages of IFN- $\gamma$-producing cells in $\mathrm{CD}^{+} \mathrm{T}$ cells were
$32.6 \%$ in the first experiment and $26.4 \%$ in the second experiment.

\section{Quantification of mRNA of Cytokines and Chemokines in $L G s$}

The relative mRNA expression levels of Th cell-related cytokines (IFN- $\gamma$, Il-4, Il-17, and Il-21), Th-related chemokines (Ccl-3, Ccl-5, Cxcl-9, Cxcl-10, Ccl-20, and Ccl22 ), and proinflammatory cytokines (Il-1 $\beta$, TNF- $\alpha$, and Il-6) in LGs of female WT and $P d c d 1^{-1-}$ mice at 4 and 6 months of age were analyzed. The mRNA expression levels of IFN$\gamma$, Ccl-5, Cxcl-9, and Ccl-20 were significantly higher in LGs in $P d c d 1^{-1-}$ mice than in those in WT mice at 4 months of age (Figure 7, C and D). Moreover, mRNA expression levels of Il-21, Cxcl-10, Il-1 $\beta$, and TNF- $\alpha$ were significantly elevated in LGs in $P d c d 1^{-1-}$ mice than in those in WT mice at 6 months of age (Figure 7, C, D, and E).

\section{Protein Expression Level of Il-21 in LGs}

As significant increase in Il-21 gene expression in LGs was detected by quantitative real-time PCR. The protein expression level of Il-21 in LGs from $P d c d 1^{-1-}$ mice at 6 months old, as measured by ELISA, was higher than that in WT mice, although the difference was not statistically significant (Figure 7F).

\section{Transfer of $\mathrm{CD}^{+}{ }^{+}$Cells or CD19 ${ }^{+} \mathrm{B}$ Cells from Pdcd1 ${ }^{-/-}$Mice into Irradiated WT Mice}

With the adoptive transfer of $\mathrm{CD} 4^{+} \mathrm{T}$ cells from $P d c d 1^{-1-}$ mice into irradiated sex-matched WT mice, dacryoadenitis developed in the LGs of recipient mice. The purity values of isolated $\mathrm{CD} 4^{+} \mathrm{T}$ cells and $\mathrm{CD} 19^{+} \mathrm{B}$ cells were $96 \%$ and 97.6\%, respectively (Supplemental Figure S2). The histologic score of inflammatory lesions in LGs in recipients of $\mathrm{CD}^{+} \mathrm{T}$ cells from $P d c d 1^{-/-}$mice was significantly higher than that in recipients of $\mathrm{CD} 4^{+} \mathrm{T}$ cells from WT mice (Figure 8A). On the other hand, dacryoadenitis was not observed in recipients of $\mathrm{CD} 19^{+} \mathrm{B}$ cells either from WT or $P d c d 1^{-1-}$ mice. There were no significant differences in histopathologic scores between groups in recipient SMGs (Figure 8B). Representative histopathology of LGs from recipient mice is shown in Figure 8C. The LGs of recipients of $\mathrm{CD}^{+} \mathrm{T}$ cells from $P d c d 1^{-1-}$ mice showed massive lymphocytic infiltration. Furthermore, the volume of tear secretion in mice recipient of $\mathrm{CD} 4^{+} \mathrm{T}$ cells from $P d c d 1^{-l-}$ mice was significantly less compared to that in those receiving cells from WT mice (Figure $8 \mathrm{D}$ ). There was no lymphocytic infiltration in the other organs, including the stomach, lung, liver, pancreas, and kidney in recipients of $\mathrm{CD} 4^{+} \mathrm{T}$ cells from $P d c d 1^{-1-}$ mice (data not shown). Flowcytometric analysis of recipient LGs was performed to determine the phenotypes of infiltrating immune cells into LGs with dacryoadenitis induced by adoptive transfer of 

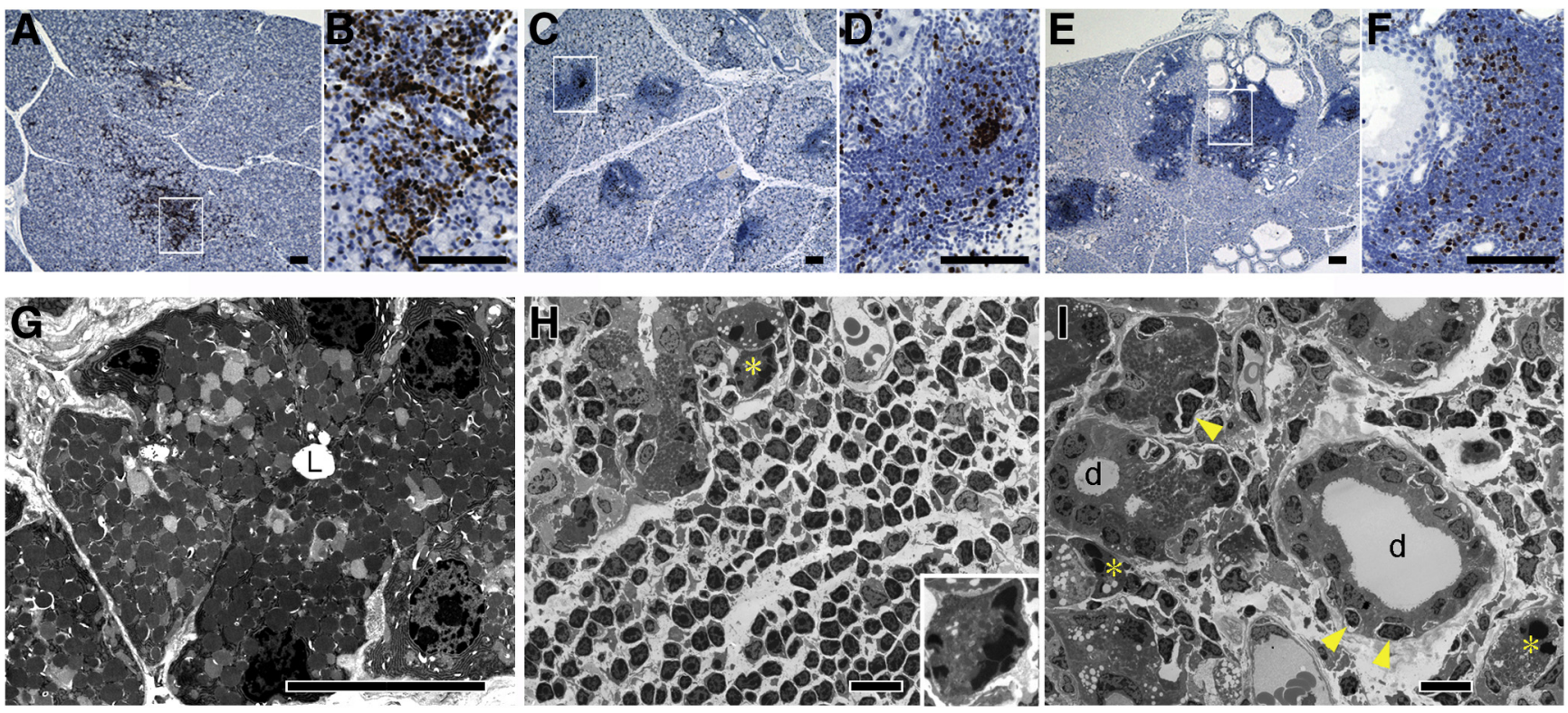

Figure 4 IHC staining for the cell-proliferation marker Ki-67 in lacrimal glands (LGs) with infiltrating cells in female $P d c d 1^{-/-}$mice, and transmission electron micrographs of an LG of a 12-month-old female $P d c d 1^{-/-}$mouse. A-F: Representative sections of Ki-67 immunostaining in extraorbital LGs from female $P d c d 1^{-1-}$ mice aged $4(\mathbf{A}$ and $\mathbf{B}), 6$ ( $(\mathbf{C}$ and $\mathbf{D})$, and 12 (E and $\left.\mathbf{F}\right)$ months. The boxed regions in $\mathbf{A}, \mathbf{C}$, and $\mathbf{E}$ correspond to $\mathbf{B}, \mathbf{D}$, and $\mathbf{F}$, respectively, at higher magnification. G: A normal acinar unit in the area without inflammatory cell infiltration. Acinar cells are apparently intact, with abundant secretion vesicles in the cytoplasm. A lumen is located at the center of the acinus (L). $\mathbf{H}$ and I: Areas with inflammatory cell infiltration. The cells in the infiltration focus are mostly lymphocytes. Some apoptotic cells with condensed and/or cleaved nuclei are observed (asterisks). The apoptotic cell with the asterisk corresponds to the inset in $\mathbf{H}$ at higher magnification. Some lymphocytes are invading into the epithelium of ducts (d) and acini (arrowheads). Scale bars: $50 \mu \mathrm{m}(\mathbf{A}-\mathbf{F})$; $10 \mu \mathrm{m}(\mathbf{G}-\mathbf{I})$.

$\mathrm{CD} 4^{+} \mathrm{T}$ cells from $P d c d 1^{-1-}$ mice. Among infiltrating cells, $\mathrm{CD}^{+} \mathrm{T}$ cells were more dominant than $\mathrm{CD} 19^{+} \mathrm{B}$ cells (Figure 8, E and G). Among infiltrating $\mathrm{CD}^{+} \mathrm{T}$ cells, both $\mathrm{CD} 4^{+} \mathrm{T}$ cells and $\mathrm{CD} 8^{+} \mathrm{T}$ cells were detected. The percentage of $\mathrm{CD} 8^{+} \mathrm{T}$ cells among $\mathrm{CD}^{+} \mathrm{T}$ cells was higher than that of $\mathrm{CD}^{+}{ }^{+} \mathrm{T}$ cells 7 weeks after the adoptive transfer of $\mathrm{CD}^{+} \mathrm{T}$ cells of $P d c d 1^{-1-}$ mice (Figure 8, F and $\mathrm{H}$ ).

\section{Discussion}

In mouse models, PD-1 deficiency leads to various types of tissue-specific autoimmune diseases, depending on their genetic background. $P d c d I^{-1-}$ mice with BALB/c background develop autoimmune cardiomyopathy. ${ }^{15}$ On the other hand, aged $P d c d 1^{-1-}$ mice with C57BL/6 background develop late-life-onset disorders in multiple organs, including the kidney, foot joint, liver, and lung. ${ }^{14,33}$ Autoimmune inflammation of the kidney and foot joint is induced in about half of the 6 month-old $P d c d I^{-/-}$mice. ${ }^{12}$

$P d c d 1^{-1-}$ mice with C57BL/6 background were used to determine whether the absence of the PD-1 pathway affected immune homeostasis in LGs. It was demonstrated, for the first time, that tear volume at 6 months of age, and saliva volume at 12 months of age, were significantly less in $P d c d I^{-1-}$ mice compared with those in WT mice. Moreover, the study showed that corneal fluorescein staining score at 6 months of age was higher in $P d c d 1^{-1-}$ mice than in WT mice. However, the score at 12 months was not significantly different, and there were no significant differences in conjunctival goblet cell density between WT and $P d c d I^{-1-}$ mice at 6 and 12 months of age. Conjunctival goblet cell loss as a dry eye-related ocular surface was not observed in $P d c d 1^{-1-}$ mice. Considering these results, this mutant mouse does not meet the specific conditions of dry eye disease.

In addition, $P d c d 1^{-1-}$ mice spontaneously developed dacryoadenitis and sialadenitis from 3 to 4 months of age. These results indicate that the age of onset of autoimmunity in LGs and SMGs is less than that in other organs in $P d c d 1^{-1-}$ mice. On comparison between dacryoadenitis and sialadenitis in $P d c d l^{-1-}$ mice, lymphocytic infiltration and structural destruction were more severe in LGs than in SMGs, which correlated with the results of the quantification of tear and saliva secretion.

The size and number of foci of lymphocytic infiltration of LGs in WT C57BL/6 mice increase with age, and are relatively mild compared to those of Sjögren syndrome model mice, and immune system changes with age in C57BL/6 mice might develop autoimmunity in LGs. ${ }^{39,40}$ The age-related increase in histopathologic scores in WT mice in the present study is consistent with the results of these studies.

The foci of infiltrating cells in LGs increased and enlarged as age increased, while Ki-67-positive infiltrating cells decreased in $P d c d 1^{-1-}$ mice. This finding may indicate that local proliferation of infiltrating cells contributes to the expansion of the foci in the early stage of dacryoadenitis. 
A

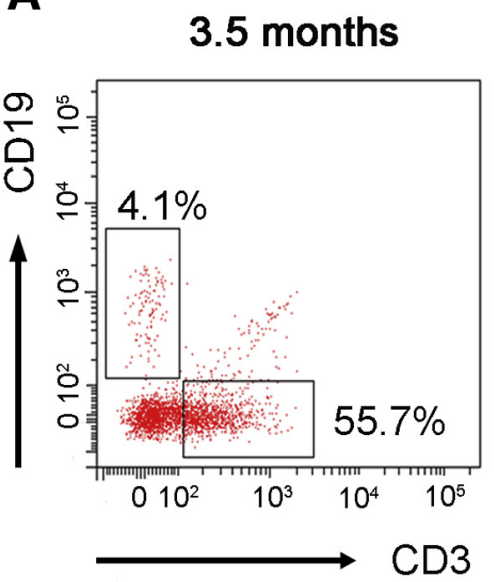

B

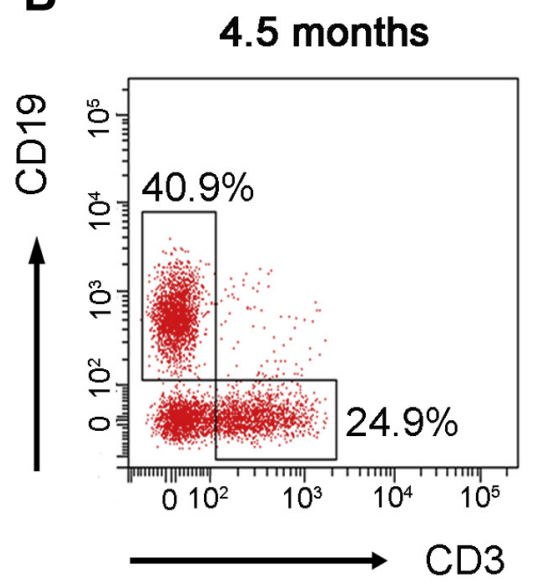

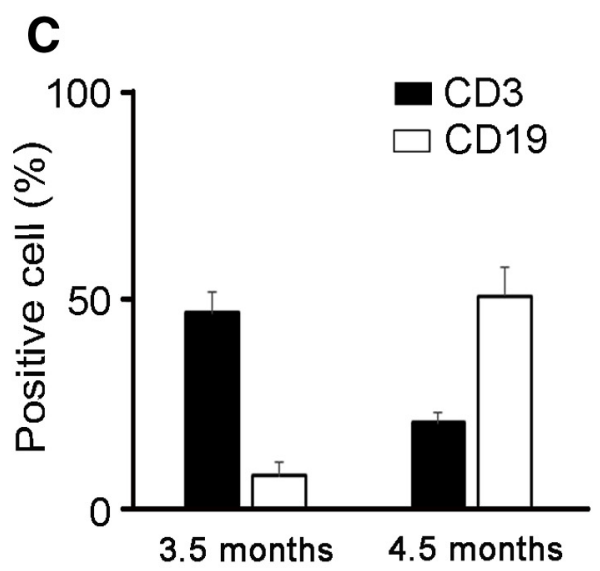

D

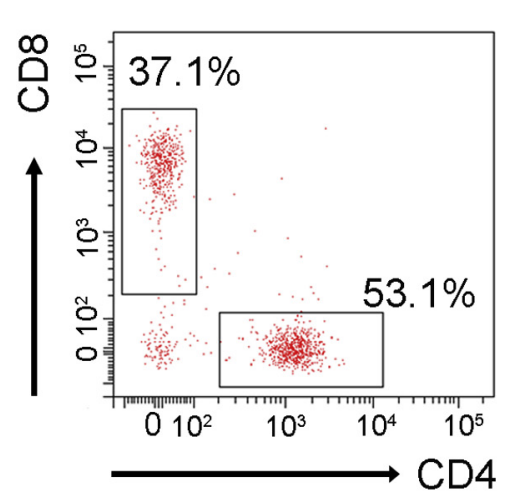

E

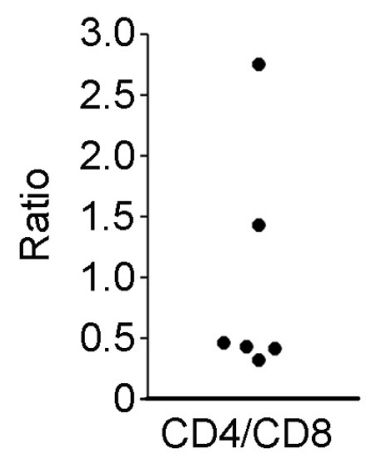

Figure 5 Types of infiltrating cells in lacrimal glands (LGs) of $P d c d 1^{-/-}$mice with dacryoadenitis. A and B: Representative fluorescence-activated cell sorting (FACS) profiles of CD45 $5^{+}$lymphocyte-gated cells stained for CD3 and CD19, in LGs in Pdcd1 ${ }^{-/}$mice aged 3.5 (A) and 4.5 months (B). C: Percentages of $\mathrm{CD}^{+} \mathrm{T}$ cells and $\mathrm{CD} 19^{+} \mathrm{B}$ cells. The dominant cells are $\mathrm{CD}^{+} \mathrm{T}$ cells at age 3.5 months, while $\mathrm{CD} 19^{+} \mathrm{B}$ cells are dominant at age 4.5 months. D: Representative FACS profiles of $\mathrm{CD}^{+} \mathrm{T}$ cell-gated cells stained for CD4 and CD8 in LGs in Pdcd1 ${ }^{-/-}$mice aged 3.5 months. E: The CD4/CD8 ratio in the LG-infiltrating CD3 ${ }^{+} \mathrm{T}$ cells in $P d c d 1^{-/-}$mice aged 3.5 months. Data are expressed as means \pm SD. $n=6$ mice per group.

Study of sex differences in autoimmune inflammation in LGs and SMGs in several mouse models of Sjögren syndrome have shown that sex differences vary among mouse strains and organs. ${ }^{41}$ Both dacryoadenitis and sialadenitis are more severe in female than in male MRL/lpr, $\mathrm{MRL}^{+}$, $\mathrm{F} 1$, and $\mathrm{C} 3 \mathrm{H} / \mathrm{lpr}$ mice. In nonobese diabetic mice, dacryoadenitis is more severe in males than in females. In $P d c d l^{-1-}$ mice, both dacryoadenitis and sialadenitis were more severe in females than in males at 6 and 12 months of age. These results indicate that sex hormones may affect the autoimmune responses leading to deterioration of dacryoadenitis and sialadenitis in aged $P d c d l^{-1-}$ mice.

The present study showed that tear volume increased in both WT and $P d c d l^{-1-}$ male mice, decreased in $P d c d 1^{-1-}$ female mice, and did not change in female WT mice, at 12 months compared with that at 6 months. The volume of tear increases in C57BL/6 mice with age, and the age-related increase of tear volume in this strain is higher in male than in female mice. ${ }^{39,40}$ The age-related increase in tear volume in male WT mice in the present study was consistent with that in the previous studies. On histologic examination, the lymphocytic infiltration and destruction of LGs in 12-month-old male and female $P d c d 1^{-1-}$ mice were very severe. Therefore, the age-related increase in tear volume in 12-month-old male WT and $P d c d 1^{-1-}$ mice might have occurred due to factors that overcome the effects of inflammation in LGs. It is known that female sex is an important risk factor for dry eye in humans, ${ }^{42,43}$ and androgens stimulate the synthesis of secretary components by LG acinar cells. ${ }^{44,45}$ Thus, lower androgen levels in female $P d c d 1^{-1-}$ mice might be the cause of less tear volume than in male $P d c d l^{-1-}$ mice, in spite of similar histologic score.

Several studies of the involvement of Th cells in the pathogenesis of Sjögren syndrome have indicated that $\mathrm{CD}^{+}{ }^{+}$Th cells play a central role, ${ }^{46}$ while Th1, -2 , and -17 subsets are related to lymphocyte infiltration in LGs and SMGs. ${ }^{47-51}$ Studies in mouse models of Sjögren syndrome have reported that dacryoadenitis in nonobese diabetic mice is a Th1-dominant immune response, ${ }^{52}$ while dacryoadenitis in MRL/MpJ mice is a Th2-dominant immune response. ${ }^{53}$ In the present study, flow-cytometric analyses demonstrated that the dominant cells infiltrating the LGs were $\mathrm{T}$ 
A
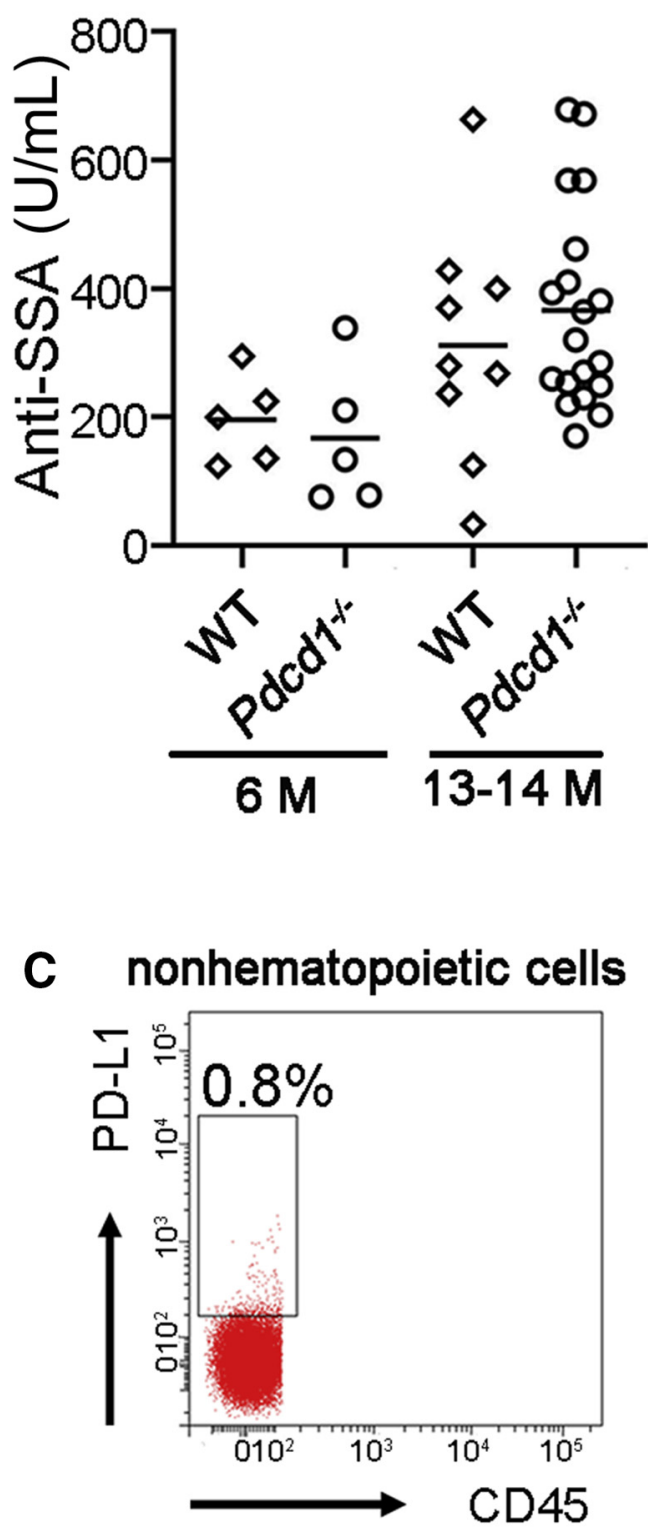

B

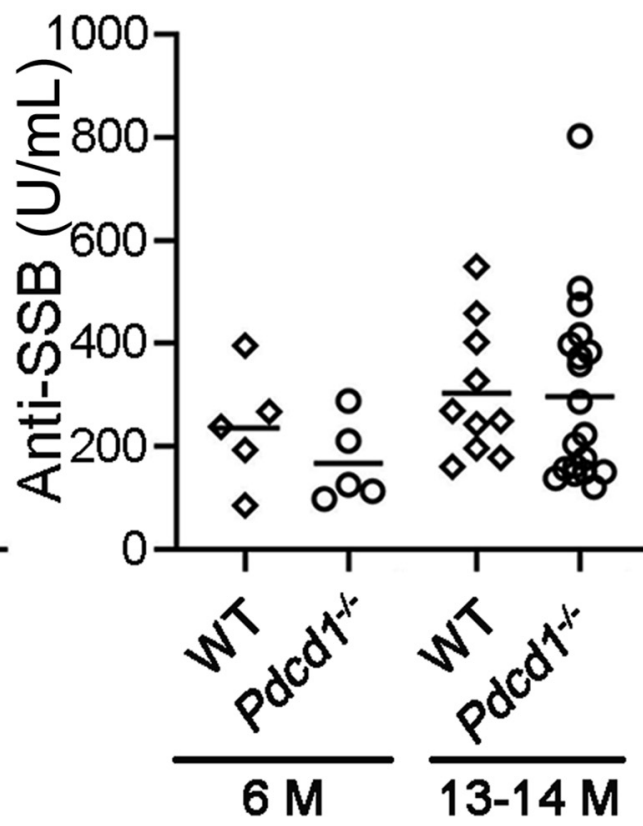

Figure 6 Serum levels of anti-SSA and anti-SSB antibodies in wild-type (WT) and $P d c d 1^{-1-}$ mice, and flow-cytometric analysis of programmed cell death protein (PD)1 ligands on nonhematopoietic cells and infiltrating cells in lacrimal glands (LGs) with dacryoadenitis in $P d c d 1^{-/-}$mice. A and B: Levels of anti-SSA (A) and anti-SSB (B) antibodies in WT and Pdcd1 ${ }^{-/-}$mice aged 6 and 13 to 14 months. Levels of both antibodies are not significantly different between WT and $P d c d 1^{-/}$mice at 6 and 13 to 14 months old. C-F: Prevalence of PD-1 ligands 1 and 2 on $\mathrm{CD}^{-} 5^{-}$nonhematopoietic cells and $\mathrm{CD} 45^{+}$hematopoietic cells in $\mathrm{LGs}$ of $P d c d 1^{-/-}$mice at age 4 months, analyzed by flow cytometry. Neither PD-L1 nor PD-L2 is detected on nonhematopoietic cells in LGs of $P d c d 1^{-/}$ mice at age 4 months ( $\mathbf{C}$ and $\mathbf{E}$ ), while many CD45 ${ }^{+}$infiltrating cells express PD-L1 (D) and PD-L2 (F). Data are representative of two independent experiments and are expressed as means (horizontal bars). $n=5\left(\mathbf{A}\right.$ and $\mathbf{B} ; \mathbf{C}-\mathbf{F}$, WT and $P d c d 1^{-/}{ }^{-}$age 6 months); $n=10$ (C-F, WT, age 13 to 14 months); $n=20$ (C-F, Pdcd1 ${ }^{-/-}$, age 13 to 14 months).

\section{E nonhematopoietic cells}

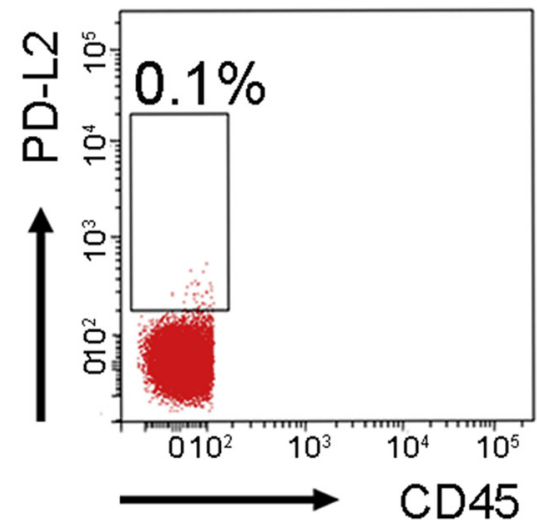

infiltrating cells

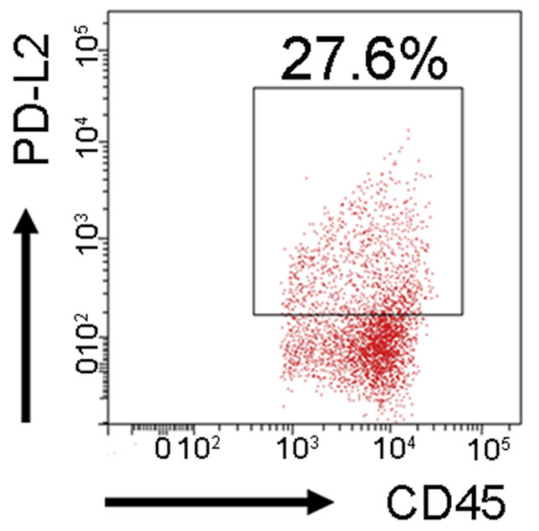


A
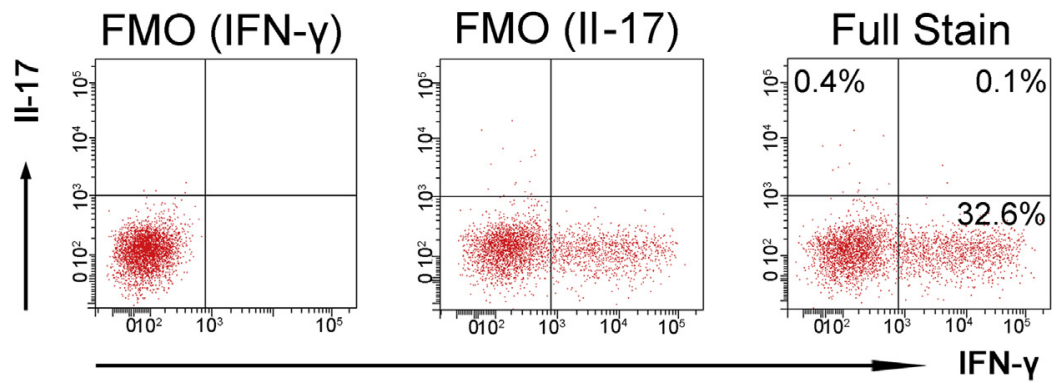

B
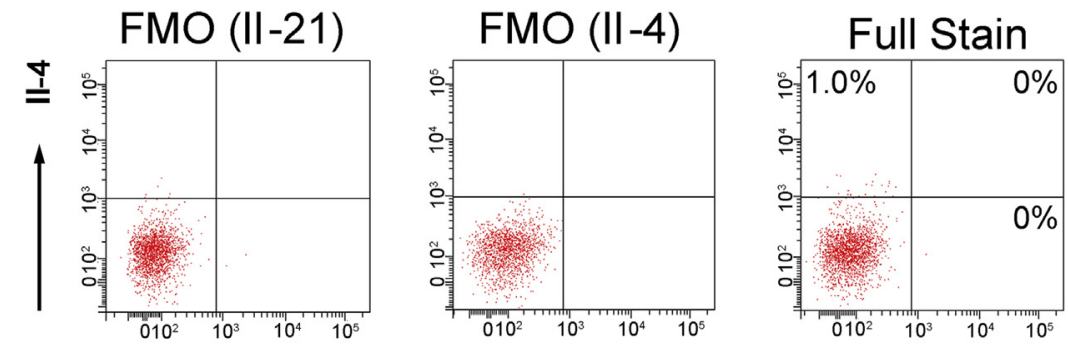

II-21

C

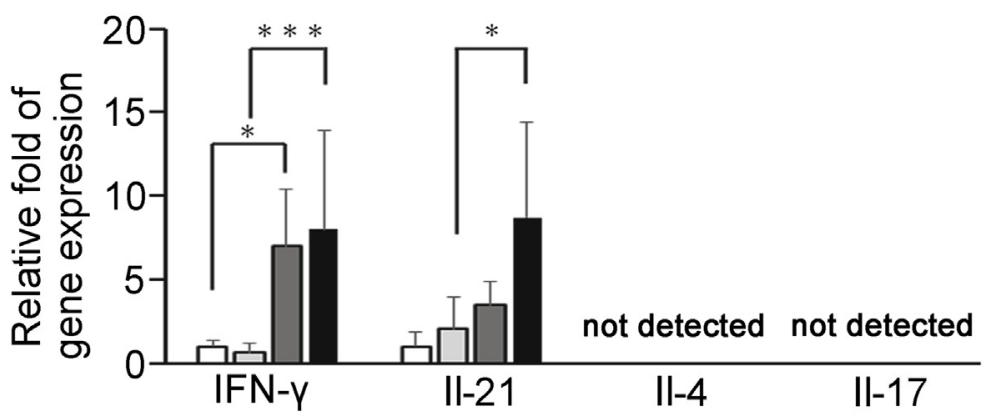

D

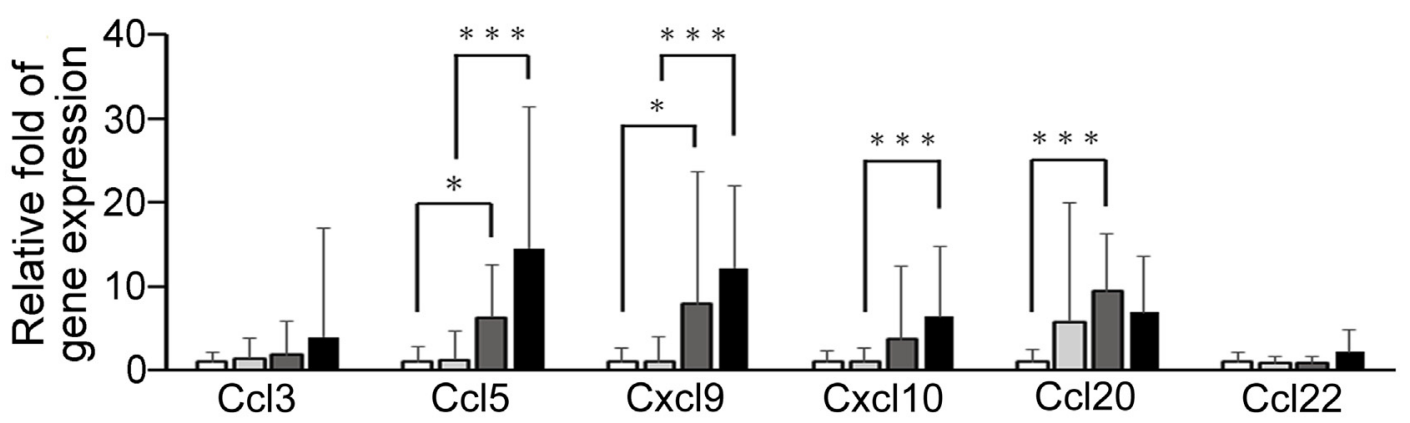

E

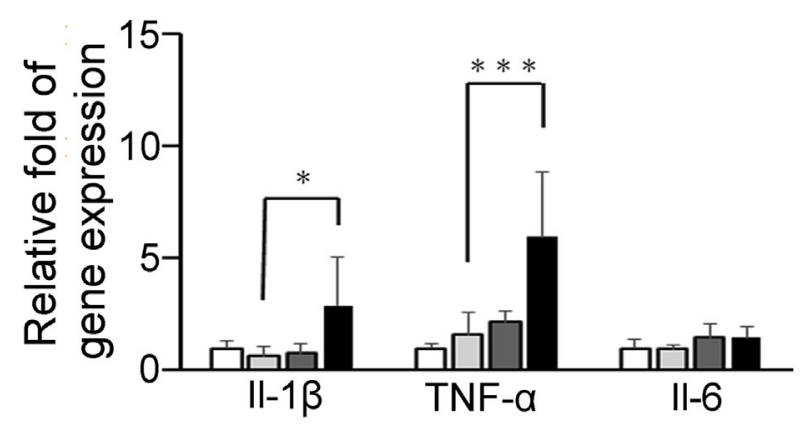

WT 4 months

WT 6 months

Pdcd 1- 4 months

Pdcd1- 6 months 
cells in the onset phase of dacryoadenitis at 3 to 4 months of age, but were replaced by $\mathrm{B}$ cells as the mice aged.

Moreover, flow-cytometric analysis of intracellular cytokine production demonstrated that only IFN- $\gamma$ (Th1- associated cytokine) was produced by the $\mathrm{CD}^{+}$Th cells infiltrating the LGs, suggesting that Th1 cells are mainly involved in the onset stage of dacryoadenitis in $P d c d 1^{-1-}$ mice. This possibility was substantiated by the study of quantitative mRNA expression. The mRNA levels of IFN- $\gamma$ and Th1-associated chemokines (Ccl-5, Cxcl-9, and Cxcl10) were significantly higher in LGs during the early stage of dacryoadenitis in $P d c d l^{-1-}$ mice compared to those in WT mice, whereas the mRNA levels of Il-4 and Il-17A were below the lower limits of detection in LGs in $P d c d l^{-/-}$ mice. Furthermore, the results of lymphocyte adaptive transfer showed that $\mathrm{CD} 4^{+} \mathrm{T}$ cells were involved in the induction of autoimmune dacryoadenitis in $P d c d I^{-1-}$ mice. These results confirmed that dacryoadenitis in $P d c d 1^{-1-}$ mice was induced by Th1-mediated immune response in the early stage, and that Th2- and Th17-mediated immune responses were not involved in pathogenesis.

In addition, we observed that lymphocytic infiltration of LGs in recipient mice was comprised of $\mathrm{CD} 4+\mathrm{T}$ cells, CD8 + T cells, and a few CD19+ B cells 7 weeks after adoptive transfer of $\mathrm{CD} 4+\mathrm{T}$ cells of Pdcd1 -/- mice. As transferred CD4+ $\mathrm{T}$ cells from Pdcd1-/- mice do not differentiate to $\mathrm{B}$ cells, $\mathrm{B}$ cells there were of recipient origin migrated to LGs by the stimulation of humoral factors such as chemokines and cytokines. Thus, these results suggest the acceleration mechanism of dacryoadenitis that $\mathrm{CD} 4+\mathrm{T}$ cells may conduct immune system which activate CD8 $+\mathrm{T}$ cells and B cells, and thereby exacerbating local inflammation. Seven weeks after the adoptive transfer of $\mathrm{CD} 4^{+} \mathrm{T}$ cells in $P d c d 1^{-1-}$ mice, $\mathrm{CD}^{+} \mathrm{T}$ cells were dominant among infiltrating immune cells in LGs, and the percentage of $\mathrm{CD}^{+} \mathrm{T}$ cells among $\mathrm{CD}^{+} \mathrm{T}$ cells was higher than that in $\mathrm{CD}^{+} \mathrm{T}$ cells, supporting this hypothetical mechanism. In the infiltrating cell population of LGs with dacryoadenitis of $P d c d 1^{-1-}$ mice, $\mathrm{CD}^{+} \mathrm{T}$ cells were dominant at 3.5 months old, while $\mathrm{CD} 19^{+} \mathrm{B}$ cells were dominant at 4.5 months old. Therefore, more B cells may appear among infiltrating cells of LGs later than 7 weeks after adoptive transfer of $\mathrm{CD} 4^{+} \mathrm{T}$ cells in $P d c d 1^{-1-}$ mice.
Tear secretion was impaired in recipients of $\mathrm{CD} 4^{+} \mathrm{T}$ cells from 4-month-old $P d c d I^{-1-}$ mice at 7 weeks after adoptive transfer. In the recipient mice of adoptive transfer, radiation induced a decrease in lymphocytes, including regulatory $\mathrm{T}$ cells, before transfer. Therefore, the decrease in regulatory $\mathrm{T}$ cells is attributed to have led to deterioration of dacryoadenitis induced by adoptive transfer of $\mathrm{CD}^{+}{ }^{+} \mathrm{T}$ cells in $P d c d 1^{-1-}$ mice, and the acceleration of impairment of tear secretion in recipient mice. These results indicate that $\mathrm{CD} 4^{+}$ Th1 cells play a crucial role in the induction of dacryoadenitis in $P d c d I^{-1-}$ mice. The inhibition of the PD-1 pathway by nivolumab treatment was reported to shift antigen-induced T-cell reactivity toward a Th1/Th17 response and suppress Th2 response in peripheral blood from patients with cancer. ${ }^{54}$ Sicca syndrome as an adverse effect of nivolumab treatment might be caused by Th1mediated immune response in LGs.

The presence of autoantibodies, either anti-SSA and/or anti-SSB antibodies in serum is one of the classification criteria for Sjögren syndrome, and has important diagnostic value. Nishimura et al ${ }^{14}$ reported that systemic lupus erythematosus-related factors such as anti-double-strand DNA antibody and rheumatoid factor were not detected in aged C57BL/6 Pdcdl ${ }^{-1-}$ mice. Although the measurements of anti-SSA and anti-SSB autoantibodies in serum were not significantly different between WT and $P d c d 1^{-1-}$ mice at 6 and 13 to 14 months of age, $P d c d 1^{-/-}$mice can still be a model of Sjögren syndrome, because of the presence of other essential features of Sjögren syndrome.

The expression of PD-L1 on nonhematopoietic cells may suppress the infiltration of autoreactive $\mathrm{T}$ cells into target organs and inhibit immune-mediated tissue damage caused by autoreactive effector cell response. ${ }^{55}$ However, as indicated by flow-cytometric analyses of LGs from $P d c d 1^{-1-}$ mice with dacryoadenitis, nonhematopoietic cells including fibroblasts and epithelial cells did not express PD-1 ligands, whereas the infiltrating lymphocytes expressed both PD-L1 and PD-L2 (Figure 6, C-F). In a previous study of dry eye in PD-L1-deficient mice, it was shown that in the absence of corneal epithelial PD-L1, dry eye-associated corneal inflammation developed. ${ }^{56}$ That study and the present study highlight the importance of the PD-1/PD-L1 pathway in the pathogenesis of dacryoadenitis and keratitis. It is also

\footnotetext{
Figure 7 Th cell-related cytokine production by $\mathrm{CD}^{+}{ }^{+} \mathrm{T}$ cells from the lacrimal glands (LGs) of female $P d c d 1^{-/-}$mice aged 4 months, mRNA expression of cytokines and chemokines in LGs of wild-type (WT) and $P d c d 1^{-/-}$mice, and the protein expression level of Il-21. A and B: Flow-cytometric analysis of CD4 ${ }^{+}$T cells isolated from LGs in $P d c d 1^{-/-}$mice aged 4 months. The percentages of interferon (IFN)- $\gamma$, Il- 4, Il-17, and Il-21 producing cells and the cells from 20 LGs of 10 female $P d c d 1^{-1-}$ mice aged 4 months were analyzed in each experiment. Fluorescence-Minus-One (FM0) controls were used to determine the cutoff points between background fluorescence and positive populations. The dot plots on the left and in the middle show FMO control, and the dot plots on the right show the full stain. In another experiment, the percentage of IFN- $\gamma$-producing cells in CD4 ${ }^{+} \mathrm{T}$ cells is $26.4 \%$. C-E: mRNA expression levels of Th cell-related cytokines (IFN- $\gamma$, Il-4, Il-17, and Il-21), Th-related chemokines [C-C motif chemokine ligand (Ccl)-3, Ccl-5, Cxcl-9, Cxcl-10, Ccl-20, and Ccl-22], and proinflammatory cytokines [Il-1 $\beta$, tumor necrosis factor (TNF)- $\alpha$, and Il-6] in lysates of LGs obtained from WT and Pdcd1 $1^{-1-}$ mice at 4 and 6 months of age, measured by quantitative real-time PCR. C: Relative gene expression of IFN- $\gamma$, IL-21, IL-4, and IL-17 in WT and Pdcd1 ${ }^{-/-}$mice at 4 and 6 months of age. D: Gene expression for Ccl-3, Ccl-5, Cxcl-9, Cxcl-10, Cxcl-20, and Cxcl22 in Wt and Pdcd1 ${ }^{-/}$mice at 4 and 6 months of age. E: Il- $1 \beta$ and TNF- $\alpha$ expressions were significantly higher in $P d c d 1^{-/-}$than in WT mice at 6 months. F: The protein expression level of Il-21 in LGs of female WT and female $P d c d 1^{-1-}$ mice at age 6 months, as measured by enzyme-linked immunosorbent assay. Data are representative of one of two independent experiments $(\mathbf{A}$ and $\mathbf{B})$ and are expressed as means $\pm \mathrm{SD} . n=5$ mice per group $(\mathbf{F}) ; n=8$ mice per group $(\mathrm{E}) .{ }^{*} P<0.05,{ }^{*} * P<0.001$ (U-test).
} 

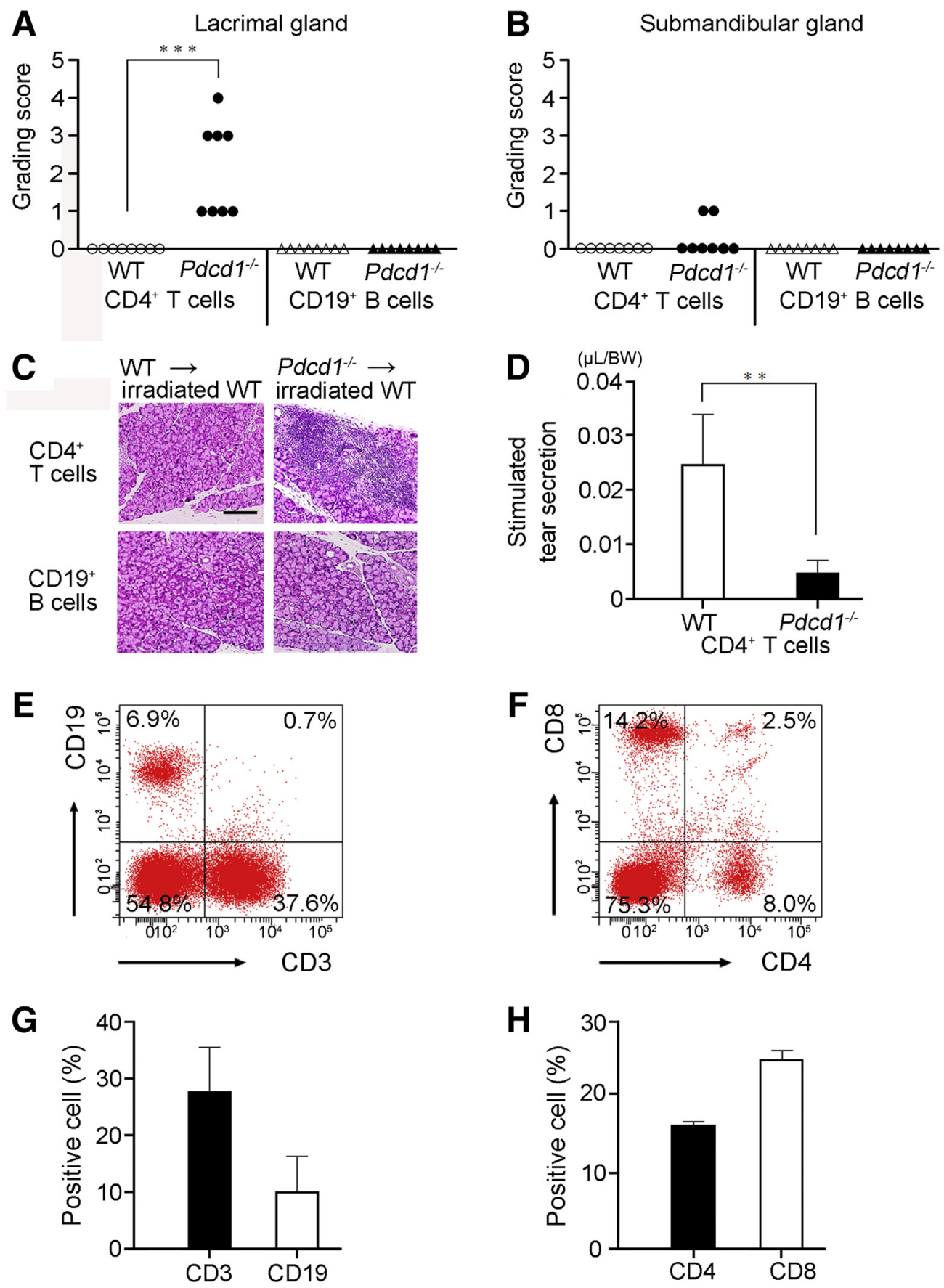

Figure 8 Adoptive transfer of lymphocytes from wild-type (WT) and $P d c d 1^{-/-}$mice into irradiated C57BL/6 mice. Histopathologic and flow-cytometric analyses of lacrimal glands (LGs) and submandibular glands (SMGs) performed at 7 weeks post-transfer. A: Histologic grading scores of inflammatory lesions in LGs of recipients. B: Histologic grading score of inflammatory lesions in SMGs of recipients. C: Representative micrographs of hematoxylin and eosin-stained sections of $L G$ s from recipients. Inflammatory lesions are observed in $\mathrm{LGs}$ of recipients of $\mathrm{CD} 4^{+} \mathrm{T}$ cells from $P d c d 1^{-/-}$mice. D: Volume of tear secretion in recipients of $\mathrm{CD}^{+}{ }^{\mathrm{T}}$ cells from WT or $P d c d 1^{-/-}$mice. E and F: Types of infiltrating cells in LGs of recipients of $\mathrm{CD} 4^{+} \mathrm{T}$ cells from $P d c d 1^{-/-}$mice. E: Representative fluorescenceactivated cell sorting (FACS) profile of CD45 $5^{+}$lymphocyte-gated cells stained for CD3 and CD19. F: Representative FACS profile of $C D 3^{+}$lymphocyte-gated cells stained for $\mathrm{CD} 4$ and CD8. G: Percentages of $\mathrm{CD}^{+} \mathrm{T}$ cells and $\mathrm{CD} 19^{+} \mathrm{B}$ cells among $\mathrm{CD} 45^{+}$lymphocytes in recipients of $\mathrm{CD} 4^{+} \mathrm{T}$ cells from Pdcd1 ${ }^{-/-}$mice. $\mathrm{H}$ : Percentages of $\mathrm{CD}^{+}{ }^{+} \mathrm{T}$ cells and $\mathrm{CD} 8^{+} \mathrm{T}$ cells among $\mathrm{CD}^{+} \mathrm{T}$ cells in recipients of $\mathrm{CD} 4^{+} \mathrm{T}$ cells from $P d c d 1^{-/-}$mice. Data are expressed as means $\pm \mathrm{SD} . n=4$ mice per group (G and $\mathbf{H}) ; n=8$ mice per group (B). ${ }^{* *} P<0.01$ (U-test), ${ }^{* *} P<0.001$ (Welch $t$-test). Scale bar $=200 \mu \mathrm{m}$. BW, body weight.

interesting that dacryoadenitis in $P d c d 1^{-1-}$ mice and dry eye-associated corneal inflammation in PD-L1-deficient mice are T-cell dominant, and chemokine expression patterns are similar, indicating that both inflammatory conditions have a similar pathogenesis. Nonetheless, the present study showed that LG tissues did not express PD-L1 in contrast to corneal epithelium, which maintain organspecific immune deviation. Moreover, the present study 
showed that dacryoadenitis in $P d c d l^{-1-}$ mice was caused by Th1 immune response and was not associated with Th17 cells. Dry eye-associated corneal inflammation is known as a Th1/Th17-related immune response, suggesting that these two types of inflammation partly share the same mechanisms.

Several studies have reported elevated levels of proinflammatory cytokines in LGs and SMGs in Sjögren syndrome patients $^{57,58}$ and animal models. ${ }^{59}$ The mRNA levels of proinflammatory cytokines such as Il-1 $\beta$ and TNF- $\alpha$ in LGs were higher in $P d c d 1^{-1-}$ mice than in WT mice at 6 months of age. The increase of proinflammatory cytokines correlated with LG secretory dysfunction in $P d c d 1^{-1-}$ mice. These results are consistent with those from previous reports that demonstrated that proinflammatory cytokines such as Il- $1 \alpha$, Il- $1 \beta$, and TNF- $\alpha$ impaired LG functions in MRL/lpr mice. ${ }^{27}$ The elevation in proinflammatory cytokines in LGs may effect a decrease in tear production in $P d c d 1^{-1-}$ mice.

Moreover, in the present study, $P d c d 1^{-l-}$ mice developed spontaneous sialadenitis and a decreased volume of saliva with aging, suggesting that the PD-1 pathway maintains immune homeostasis not only in LGs but also in the salivary glands.

In the present study, the role of PD-1 in the regulation of immune homeostasis in LGs was investigated. The results indicate that $\mathrm{CD}_{4}^{+}$Th1 cells may contribute to the development of autoimmune dacryoadenitis, and PD-1 ligands were expressed on infiltrating cells in LGs but not in tissues of LG itself in $P d c d I^{-1-}$ mice. These results also suggest that the PD-1 pathway could suppress the development of autoreactive lymphocytes against LGs, and that PD-1 plays an important role in the maintenance of immune homeostasis in LGs. This study provides an etiologic basis for sicca syndrome induced by anti-PD-1 drugs such as nivolumab.

\section{Acknowledgments}

We thank Asami Taguchi for technical assistance with the experiments. We are grateful to Dr. Ikkou Kashiwagi for useful discussions.

\section{Author Contributions}

Y.U., T.H., and M.T. conceived and designed the research; Y.S., Y.N., Y.K., and N.Y. conducted the experiments and analyzed the data; Y.S., M.T., and M.I. interpreted the results of the experiments; Y.S., K.T., Y.K., and M.I. wrote the manuscript; H.G., D.S., M.T., and M.I. edited and revised the manuscript; all of the authors approved the final version of the manuscript.

\section{Supplemental Data}

Supplemental material for this article can be found at https://doi.org/10.1016/j.ajpath.2021.02.014.

\section{References}

1. Sharpe AH, Freeman GJ: The B7-CD28 superfamily. Nat Rev Immunol 2002, 2:116-126

2. Chen L: Co-inhibitory molecules of the B7-CD28 family in the control of T-cell immunity. Nat Rev Immunol 2004, 4:336-347

3. Tivol EA, Borriello F, Schweitzer AN, Lynch WP, Bluestone JA, Sharpe AH: Loss of CTLA-4 leads to massive lymphoproliferation and fatal multiorgan tissue destruction, revealing a critical negative regulatory role of CTLA-4. Immunity 1995, 3:541-547

4. Oya Y, Watanabe N, Owada T, Oki M, Hirose K, Suto A, Kagami S, Nakajima H, Kishimoto T, Iwamoto I, Murphy TL, Murphy KM, Saito Y: Development of autoimmune hepatitis-like disease and production of autoantibodies to nuclear antigens in mice lacking B and T lymphocyte attenuator. Arthritis Rheum 2008, 58:2498-2510

5. Ishida Y, Agata Y, Shibahara K, Honjo T: Induced expression of PD1, a novel member of the immunoglobulin gene superfamily, upon programmed cell death. EMBO J 1992, 11:3887-3895

6. Agata Y, Kawasaki A, Nishimura H, Ishida Y, Tsubat T, Yagita H, Honjo T: Expression of the PD-1 antigen on the surface of stimulated mouse T and B lymphocytes. Int Immunol 1996, 8:765-772

7. Okazaki T, Maeda A, Nishimura H, Kurosaki T, Honjo T: PD-1 immunoreceptor inhibits B cell receptor-mediated signaling by recruiting Src homology 2-domain-containing tyrosine phosphatase 2 to phosphotyrosine. Proc Natl Acad Sci U S A 2001, 98: 13866-13871

8. Okazaki T, Honjo T: PD-1 and PD-1 ligands: from discovery to clinical application. Int Immunol 2007, 19:813-824

9. Freeman GJ, Long AJ, Iwai Y, Bourque K, Chernova T, Nishimura H, Fitz LJ, Malenkovich N, Okazaki T, Byrne MC, Horton HF, Fouser L, Carter L, Ling V, Bowman MR, Carreno BM, Collins M, Wood CR, Honjo T: Engagement of the PD-1 immunoinhibitory receptor by a novel B7 family member leads to negative regulation of lymphocyte activation. J Exp Med 2000, 192: $1027-1034$

10. Hori J, Wang M, Miyashita M, Tanemoto $\mathrm{K}$, Takahashi $\mathrm{H}$, Takemori T, Okumura K, Yagita H, Azuma M: B7-H1-induced apoptosis as a mechanism of immune privilege of corneal allografts. J Immunol 2006, 177:5928-5935

11. Sham CW, Chan AM, Kwong JM, Caprioli J, Nusinowitz S, Chen B, Lee JG, Gandhi NM, Francisco LM, Sharpe AH, Chen L, Braun J, Gordon LK: Neuronal programmed cell death-1 ligand expression regulates retinal ganglion cell number in neonatal and adult mice. J Neuroophthalmol 2012, 32:227-237

12. Latchman Y, Wood CR, Chernova T, Chaudhary D, Borde M Chernova I, Iwai Y, Long AJ, Brown JA, Nunes R, Greenfield EA, Bourque K, Boussiotis VA, Carter LL, Carreno BM, Malenkovich N, Nishimura H, Okazaki T, Honjo T, Sharpe AH, Freeman GJ: PD-L2 is a second ligand for PD-1 and inhibits $\mathrm{T}$ cell activation. Nat Immunol 2001, 2:261-268

13. Dai S, Jia R, Zhang X, Fang Q, Huang L: The PD-1/PD-Ls pathway and autoimmune diseases. Cell Immunol 2014, 290:72-79

14. Nishimura H, Nose M, Hiai H, Minato N, Honjo T: Development of lupus-like autoimmune diseases by disruption of the PD-1 gene encoding an ITIM motif-carrying immunoreceptor. Immunity 1999 , $11: 141-151$

15. Nishimura H, Okazaki T, Tanaka $Y$, Nakatani $K$, Hara M, Matsumori A, Sasayama S, Mizoguchi A, Hiai H, Minato N, 
Honjo T: Autoimmune dilated cardiomyopathy in PD-1 receptordeficient mice. Science 2001, 291:319-322

16. Suarez-Gestal M, Ferreiros-Vidal I, Ortiz JA, Gomez-Reino JJ, Gonzalez A: Analysis of the functional relevance of a putative regulatory SNP of PDCD1, PD1.3, associated with systemic lupus erythematosus. Genes Immun 2008, 9:309-315

17. Kong EK, Prokunina-Olsson L, Wong WH, Lau CS, Chan TM, Alarcon-Riquelme M, Lau YL: A new haplotype of PDCD1 is associated with rheumatoid arthritis in Hong Kong Chinese. Arthritis Rheum 2005, 52:1058-1062

18. Buchbinder EI, Desai A: CTLA-4 and PD-1 pathways: similarities, differences, and implications of their inhibition. Am J Clin Oncol 2016, 39:98-106

19. Byun DJ, Wolchok JD, Rosenberg LM, Girotra M: Cancer immunotherapy - immune checkpoint blockade and associated endocrinopathies. Nat Rev Endocrinol 2017, 13:195-207

20. Postow MA, Sidlow R, Hellmann MD: Immune-related adverse events associated with immune checkpoint blockade. N Engl J Med 2018, 378:158-168

21. Tocut M, Brenner R, Zandman-Goddard G: Autoimmune phenomena and disease in cancer patients treated with immune checkpoint inhibitors. Autoimmun Rev 2018, 17:610-616

22. Cappelli LC, Gutierrez AK, Baer AN, Albayda J, Manno RL, Haque U, Lipson EJ, Bleich KB, Shah AA, Naidoo J, Brahmer JR, Le D, Bingham CO 3rd: Inflammatory arthritis and sicca syndrome induced by nivolumab and ipilimumab. Ann Rheum Dis 2017, 76: $43-50$

23. Delaleu N, Jonsson R, Koller MM: Sjogren's syndrome. Eur J Oral Sci 2005, 113:101-113

24. van Blokland SC, van Helden-Meeuwsen CG, Wierenga-Wolf AF, Drexhage HA, Hooijkaas H, van de Merwe JP, Versnel MA: Two different types of sialoadenitis in the NOD- and MRL/lpr mouse models for Sjogren's syndrome: a differential role for dendritic cells in the initiation of sialoadenitis? Lab Invest 2000, 80:575-585

25. Edwards JC, Wilkinson LS, Speight P, Isenberg DA: Vascular cell adhesion molecule 1 and alpha 4 and beta 1 integrins in lymphocyte aggregates in Sjogren's syndrome and rheumatoid arthritis. Ann Rheum Dis 1993, 52:806-811

26. Jabs DA, Prendergast RA: Murine models of Sjogren's syndrome. Immunohistologic analysis of different strains. Invest Ophthalmol Vis Sci 1988, 29:1437-1443

27. Zoukhri D, Hodges RR, Byon D, Kublin CL: Role of proinflammatory cytokines in the impaired lacrimation associated with autoimmune xerophthalmia. Invest Ophthalmol Vis Sci 2002, 43: $1429-1436$

28. Voulgarelis M, Tzioufas AG: Pathogenetic mechanisms in the initiation and perpetuation of Sjogren's syndrome. Nat Rev Rheumatol 2010, 6:529-537

29. Li H, Dai M, Zhuang Y: A T cell intrinsic role of Id3 in a mouse model for primary Sjögren's syndrome. Immunity 2004, 21:551-560

30. Rashid S, Jin Y, Ecoiffier T, Barabino S, Schaumberg DA, Dana MR: Topical omega-3 and omega- 6 fatty acids for treatment of dry eye. Arch Ophthalmol 2008, 126:219-225

31. Lemp MA: Report of the National Eye Institute/Industry workshop on clinical trials in dry eyes. CLAO J 1995, 21:221-232

32. White SC, Casarett GW: Induction of experimental autoallergic sialadenitis. J Immunol 1974, 112:178-185

33. Liu J, Yuan Y, Chen W, Putra J, Suriawinata AA, Schenk AD, Miller HE, Guleria I, Barth RJ, Huang YH, Wang L: Immunecheckpoint proteins VISTA and PD-1 nonredundantly regulate murine T-cell responses. Proc Natl Acad Sci U S A 2015, 112: $6682-6687$

34. Corrales RM, de Paiva CS, Li DQ, Farley WJ, Henriksson JT, Bergmanson JP, Pflugfelder SC: Entrapment of conjunctival goblet cells by desiccation-induced cornification. Invest Ophthalmol Vis Sci 2011, 52:3492-3499
35. Ito M, Yoshioka M: Regression of the hyaloid vessels and pupillary membrane of the mouse. Anat Embryol 1999, 200:403-411

36. Turpie B, Yoshimura T, Gulati A, Rios JD, Dartt DA, Masli S: Sjogren's syndrome-like ocular surface disease in thrombospondin-1 deficient mice. Am J Pathol 2009, 175:1136-1147

37. Iizuka M, Tsuboi H, Matsuo N, Asashima H, Hirota T, Kondo Y, Iwakura Y, Takahashi S, Matsumoto I, Sumida T: A crucial role of RORgammat in the development of spontaneous Sialadenitis-like Sjogren's syndrome. J Immunol 2015, 194:56-67

38. Schmittgen TD, Livak KJ: Analyzing real-time PCR data by the comparative C(T) method. Nat Protoc 2008, 3:1101-1108

39. McClellan AJ, Volpe EA, Zhang X, Darlington GJ, Li DQ, Pflugfelder SC, de Paiva CS: Ocular surface disease and dacryoadenitis in aging C57BL/6 mice. Am J Pathol 2014, 184: 631-643

40. Shikama Y, Kurosawa M, Furukawa M, Ishimaru N, Matsushita K: Involvement of adiponectin in age-related increases in tear production in mice. Aging 2019, 11:8329-8346

41. Toda I, Sullivan BD, Rocha EM, Da Silveira LA, Wickham LA, Sullivan DA: Impact of gender on exocrine gland inflammation in mouse models of Sjogren's syndrome. Exp Eye Res 1999, 69: 355-366

42. Lin PY, Tsai SY, Cheng CY, Liu JH, Chou P, Hsu WM: Prevalence of dry eye among an elderly Chinese population in Taiwan: the Shihpai eye study. Ophthalmology 2003, 110:1096-1101

43. McCarty CA, Bansal AK, Livingston PM, Stanislavsky YL, Taylor HR: The epidemiology of dry eye in Melbourne, Australia. Ophthalmology 1998, 105:1114-1119

44. Sullivan DA, Kelleher RS, Vaerman JP, Hann LE: Androgen regulation of secretory component synthesis by lacrimal gland acinar cells in vitro. J Immunol 1990, 145:4238-4244

45. Gao J, Lambert RW, Wickham LA, Banting G, Sullivan DA: Androgen control of secretory component mRNA levels in the rat lacrimal gland. J Steroid Biochem Mol Biol 1995, 52: 239-249

46. Adamson TC 3rd, Fox RI, Frisman DM, Howell FV: Immunohistologic analysis of lymphoid infiltrates in primary Sjogren's syndrome using monoclonal antibodies. J Immunol 1983, 130:203-208

47. Mitsias DI, Tzioufas AG, Veiopoulou C, Zintzaras E, Tassios IK, Kogopoulou O, Moutsopoulous HM, Thyphronitis G: The Th1/Th2 cytokine balance changes with the progress of the immunopathological lesion of Sjogren's syndrome. Clin Exp Immunol 2002, 128:562-568

48. Moriyama M, Hayashida J-N, Toyoshima T, Ohyama Y, Shinozaki S, Tanaka A, Maehara T, Nakamura S: Cytokine/chemokine profiles contribute to understanding the pathogenesis and diagnosis of primary Sjogren's syndrome. Clin Exp Immunol 2012, 169:17-26

49. Maehara T, Moriyama M, Hayashida JN, Tanaka A, Shinozaki S, Kubo Y, Matsumura K, Nakamura S: Selective localization of T helper subsets in labial salivary glands from primary Sjogren's syndrome patients. Clin Exp Immunol 2012, 169:89-99

50. Kolkowski EC, Reth P, Pelusa F, Bosch J, Pujol-Borrell R, Coll J, Jaraquemada D: Th1 predominance and perforin expression in minor salivary glands from patients with primary Sjogren's syndrome. J Autoimmun 1999, 13:155-162

51. Ohyama Y, Nakamura S, Matsuzaki G, Shinohara M, Hiroki A, Fujimura T, Yamada A, Itoh K, Nomoto K: Cytokine messenger RNA expression in the labial salivary glands of patients with Sjogren's syndrome. Arthritis Rheum 1996, 39:1376-1384

52. Takahashi M, Ishimaru N, Yanagi K, Haneji N, Saito I, Hayashi Y: High incidence of autoimmune dacryoadenitis in male non-obese diabetic (NOD) mice depending on sex steroid. Clin Exp Immunol 1997, 109: 555-561

53. Jabs DA, Lee B, Whittum-Hudson JA, Prendergast RA: Th1 versus Th2 immune responses in autoimmune lacrimal gland disease in MRL/Mp mice. Invest Ophthalmol Vis Sci 2000, 41:826-831 
54. Dulos J, Carven GJ, van Boxtel SJ, Evers S, Driessen-Engels LJ, Hobo W, Gorecka MA, de Haan AF, Mulders P, Punt CJ, Jacobs JF, Schalken JA, Oosterwijk E, van Eenennaam H, Boots AM: PD-1 blockade augments Th1 and Th17 and suppresses Th2 responses in peripheral blood from patients with prostate and advanced melanoma cancer. J Immunother 2012, 35:169-178

55. Keir ME, Liang SC, Guleria I, Latchman YE, Qipo A, Albacker LA, Koulmanda M, Freeman GJ, Sayegh MH, Sharpe AH: Tissue expression of PD-L1 mediates peripheral T cell tolerance. J Exp Med 2006, 203:883-895

56. El Annan J, Goyal S, Zhang Q, Freeman GJ, Sharpe AH, Dana R: Regulation of T-cell chemotaxis by programmed death-ligand 1
(PD-L1) in dry eye-associated corneal inflammation. Invest Ophthalmol Vis Sci 2010, 51:3418-3423

57. Saito I, Terauchi K, Shimuta M, Nishiimura S, Yoshino K, Takeuchi T, Tsubota K, Miyasaka N: Expression of cell adhesion molecules in the salivary and lacrimal glands of Sjogren's syndrome. J Clin Lab Anal 1993, 7:180-187

58. Fox RI, Kang HI, Ando D, Abrams J, Pisa E: Cytokine mRNA expression in salivary gland biopsies of Sjogren's syndrome. J Immunol 1994, 152:5532-5539

59. Hamano H, Saito I, Haneji N, Mitsuhashi Y, Miyasaka N, Hayashi Y: Expressions of cytokine genes during development of autoimmune sialadenitis in MRL/lpr mice. Eur J Immunol 1993, 23:2387-2391 